\title{
Climatic and social factors behind the Spanish Mediterranean flood event chronologies from documentary sources (14th-20th centuries)
}

Mariano Barriendos ${ }^{1, *}$ mbarriendos@ub.edu, Salvador Gil-Guirado ${ }^{2}$, David Pino ${ }^{3,4}$, Jordi Tuset ${ }^{5}$; Alfredo Pérez-Morales ${ }^{6}$, Armando Alberola ${ }^{7}$, Joan Costa ${ }^{1}$, Josep Carles Balasch ${ }^{8}$, Xavier Castelltort $^{8}$, Jordi Mazón ${ }^{3}$, Josep Lluis Ruiz-Bellet ${ }^{8}$

${ }^{1}$ Department of History and Archaeology, University of Barcelona, Montalegre 6, 08001 Barcelona, Spain

${ }^{2}$ Interuniversity Institute of Geography, University of Alicante, P.O. Box 99, 03080 Alicante, Spain

${ }^{3}$ Department of Physics, Universitat Politècnica de Catalunya·BarcelonaTech, Esteve Terrades 5, 08860

Castelldefels, Spain

${ }^{4}$ Institute of Space Studies of Catalonia (CTE-UPC), Gran Capità 2-4, 08034 Barcelona, Spain

${ }^{5}$ Fluvial Dynamics Research Group, University of Lleida, Rovira Roure 191, 25198 Lleida, Spain

${ }^{6}$ Department of Geography, University of Murcia, Campus de la Merced, 30001 Murcia, Spain

${ }^{7}$ Department of Medieval History, Modern History and Historiographic Sciences and Techniques, Facultad de Filosofía y Letras, University of Alicante, P.O Box 99, 03080 Alicante, Spain

${ }^{8}$ Department of Environment and Soil Sciences, University of Lleida, Rovira Roure 191, 25198 Lleida, Spain

${ }^{*}$ Corresponding author. 


\begin{abstract}
The Spanish Mediterranean river basin provides a good background for studying floods from documentary and bibliographical sources within the specialty of historical climatology. This study region's long history of human occupation and climatic conditions together determine a high risk of flooding. As a result, there exists an enormous amount of documentary heritage containing flood information. However, the heterogeneity of documentary sources and different approaches to classifying floods through historical documents can generate some biases and uncertainties about the quantity and quality of the available data.

For this reason, this paper proposes a methodology for reconstructing historical floods based on cross-referencing documentary sources. This approach, together with additional archival work, has allowed us to increase the number of flood series for the Spanish Mediterranean coast by $17 \%$ and has generated a surprising increase of $233 \%$ in the number of flood cases detected.

The data obtained have allowed us to analyze the variability of floods and their relationship with climatic and social factors from the fourteenth century to the present. Different climatic oscillations related to the Little Ice Age are detected between the 14th and 19th centuries. Additionally, we detected a strong influence of the defense infrastructures and urban growth, which explain the recent flood trends. However, the difficulty in analyzing the influence of social factors on long-term flood behavior invites us to reflect on the need for further work for emphasizing these issues.
\end{abstract}

Keywords: Climatic Variability; Documentary Sources; Floods; Little Ice Age; Vulnerability; Western Mediterranean Basin 


\section{Introduction}

Hydrometeorological extreme events have historically been a concern in the Mediterranean basin. Specifically, persistent and torrential rainfall produces severe events in fluvial areas, including overfloods that highly impact natural and social ambits. These floods have a structural character in the Mediterranean climate, which includes large drought periods combined with torrential rainfall episodes and convective events. This occurs due to the convergence of air masses and sea-air interactions, as well as local factors such as complex orography (Roberts et al., 2011).

Natural climate variability manifests itself with great sensitivity and a large frequency of extreme events. Human beings have coped with these conditions in a continuous effort to secure water resources while reducing exposure and vulnerability. Preserved testimonies over a long period of time allow reconstructing and analyzing the natural behaviors while establishing the forcing factors that have influences at different spatio-temporal scales (Roberts et al., 2011).

Regarding torrential rainfall and the associated floods, humans are becoming increasingly exposed and vulnerable, which in turn generates the perception of an increasing impact from these types of events (Toreti et al., 2010). Floods have produced a large impact on the Mediterranean area over the last decades. According to the Emergency Events Database (CRED, 2009) for the years between 1950 and 2009, 19 countries in the Mediterranean basin recorded 395 severe extreme events, producing losses estimated at 64 billion dollars, 9904 deaths and affecting around 12 million people who required help because they were injured, homeless or their basic services were affected (Toreti et al., 2010).

Consequently, historical flood reconstructions have two objectives: first, to define flood climatic variability in order to establish the factors that influence the spatiotemporal distribution and magnitude; and, second, to understand the socio-economic processes that interact with the frequency and severity of the floods. When both objectives achieve optimal results, they could establish the precise influence of climate change on extreme events.

Different sources of information contribute to this effort, and paleoclimatic specialties have been developed to study proxies related to sediments (i.e., Gregory et al., 1995; Schulte et al., 2019), biology (i.e., Díez-Herrero et al., 2013a; Ruiz-Villanueva et al., 2013; DíezHerrero et al., 2013b) or to history. This last approach is also defined as historical hydrology, and it reconstructs flood events by using dense and reliable handwritten historical documentary backgrounds to include the largest quantitative data available (Brázdil et al., 2006; Wetter et al., 2011).

Historical hydrology allows detecting and reconstructing flood events with high temporal resolution and precise dating. Developing large databases enables the analysis of climatic variability, low frequency climatic patterns, and their interactions with the rainfall regime (i.e., Glaser et al., 2010; Glaser, 2012; Macdonald and Sangster, 2017). The quantitative component of the information also allows for hydraulic reconstruction of historical events by obtaining maximum peak flows, flood areas and other parameters (Thorndycraft et al., 2006; Ruiz-Bellet et al., 2015).

Over the last decades, historical hydrology has become increasingly important due to the uncertain influence of global warming on the occurrence and severity of extreme hydrometeorological events. For instance, torrential precipitation during the period 19502006 represented $60 \%$ of the total precipitation in the Mediterranean area, without any significant positive tendency (Toreti et al., 2010). Climatic projections (Barrera-Escoda and Cunillera, 2011) for Catalonia (NE Spain) indicate a decrease of up to $30 \%$ of the total annual precipitation while a $30 \%$ increase is seen for the number of days with torrential precipitation $\left(>100 \mathrm{~mm} \mathrm{day}^{-1}\right)$. 
Consequently, additional knowledge of past flood events is needed to evaluate present variability and future tendencies before being able to establish sustainable management of impacts. By studying historical flood events using series of the longest available temporal length, the ability to manage future risk is improved, particularly when we consider the present uncertainty and difficulties in defining consistent links between climate change and flood frequency patterns (Brázdil et al., 2006; Füssel, 2012; Salinas et al., 2016).

The main objective of the present work is largely to increase our knowledge of the floods in the Spanish Mediterranean area by improving two different research aspects:

- Confirmation of the low frequency patterns already shown in previous works (Barriendos and Martin-Vide, 1998; Barriendos and Rodrigo, 2006).

- Ascertaining whether the larger amount of information qualifies these previous results or gives new patterns.

In this work, we do not deal directly with the causes producing floods on a climatic scale. Different works have already studied this point and obtained results that are not clearly defined due to the complexity of the interactions and scarce number of analyzed events.

On the other hand, we include recent socio-economic factors in the analysis in order to understand the different patterns of the floods when comparing them with the historical preindustrial period. Detecting and quantifying these patterns will allow for better adaptive strategies for facing climatic and social changes.

Forest and bushes are adapted to the water stress and long drought periods, thus presenting great biodiversity in accordance with the local climates caused by the orography. Human presence has occupied the territory since the Roman period, with extensive rainfed agriculture and intensive irrigation in some low-lying areas. Since then, the traditional cereal crops, vineyards and olive trees have hardly changed in the interior and mid-mountain areas. On the other hand, the coastal areas evolved rapidly over the 20th century due to the abandonment of agriculture and the growth of a strong population based on industrial activities, services and tourism activities. Meanwhile, the mountainous regions during the same period saw the disappearance of traditional agricultural activities, strong depopulation, and spontaneous reforestation processes.

The occupation of the territory has led to processes of evident interaction with the river systems in the low and river mouth areas: deforestation, regulation of river basins, occupation of floodplains, the intersection and modification of riverbeds, and even lost memories regarding the location of the torrents, or ephemeral river courses.

The existing basins have very different dimensions, so the rivers have very different characteristics, from large river courses to ephemeral rivers (ramblas, torrentes, rieres, barrancos, arroyos, depending on the different local denominations) that only flow when a flood event occurs or during a very wet period. The human presence has a long history with different activities in the channels and water resources: irrigation (dams, canals), energy production (hydraulic mills), urban supply (dams, wells, pipelines) and the growth of urban areas that have undergone interventions to prevent flooding (large reservoirs, protection dams, secondary riverbeds, water tanks against storms, drainage networks, etc.).

\section{Material and methods}

\subsection{Study area}

The study area is the eastern part of the Iberian Peninsula, where the rivers flow into the Mediterranean Sea (see Fig. 1, Table 1) and the lithological, edaphological and orographic characteristics are complex and heterogeneous. This region's Mediterranean climate presents 
some variances between the different areas, although some common characteristics exist: large drought periods and torrential precipitation with great spatial and temporal irregularity. Annual mean temperature varies from north to south, from $15.4^{\circ} \mathrm{C}$ (Girona) to $19.5^{\circ} \mathrm{C}$ (Murcia). Total annual precipitation decreases from north to south: 1000/1200 mm (Pyrenees Mts. headwaters), 700/750 mm (Girona, La Seu d'Urgell), 450/550 mm (Barcelona, Valencia), and 200/300 mm (Almería, Murcia).

\subsection{Compilation, indexing and classification of the information}

Historical flood compilation followed the methodology proposed by Barriendos and MartinVide (1998) and Brázdil et al. (1999) to obtain chronologies for interpreting low frequency flood patterns. The increase in the amount of available information allows for multi-proxy reconstructions of the meteorological and hydrological processes related to floods (Thorndycraft et al, 2006; Ruiz-Bellet et al., 2015; Pino et al., 2016; Balasch et al., 2019), and methodological improvements for indexing and classifying flood cases. For instance, different sources used in the compilation can be cross-checked by following these sources' temporal threads of the same cases. This traceability principle provides not only details over time for the different sources but also the changes that can appear. In this way, we were able to develop a flood category that consisted of false cases generated at different moments due to errors in transcription, translation or interpretation. Obviously, this category has been excluded from the analysis and the reliability of our information is consequently improved (Barriendos et al., 2014).

We also enhanced the historical flood cataloging systems. Traditional works focused on specific locations, cities or points of particular exposure and vulnerability while reconstructing cases to generate chronologies of varying lengths, depending on the availability of the sources. Nowadays, the indexing procedure includes and organizes all detected data from any origin, because the density of information and variety of details produces more consistent and reliable results for meteorological and hydrological reconstructions.

In the present work, we update the chronologies already published in contributions from the past 12 years of research projects (among others, EC MILLENNIUM IP 017008-2, HAR2009-11928, HAR2013-44972-P, PREDIFLOOD, and MEDIFLOOD), PhD research projects (Gil-Guirado, 2013; García-Torres, 2015), the bibliographies of co-authors (Alberola, 2010; Alberola, 2017; Balasch et al., 2019; García-Torres, 2016; Pérez-Morales et al., 2018) and unpublished original works on elaborating new chronologies.

In selecting the data for the present work, we took a classical approach and arrived at 2467 flood cases for 18 chronological series. The available catalogue consists of 4244 cases for Catalonia (NE Spain) alone, and a similar quantity exists for the rest of the Spanish Mediterranean coast. In the near future, the chronologies will not cover specific places, but separate chronologies for each flood event will include all the available information on different places and river basins.

The classification system of three categories was proposed in previous works on the studied area and for other European basins (Barriendos and Martin-Vide, 1998; Wetter et al. 2011; see Table 2):

1. Ordinary (ORD) floods that consist of simple flow increases are not considered here because of the large number of cases included in this category. The first step of analysis suggests focusing efforts on more severe events. Additionally, documentary sources are not temporarily homogeneous in registering this type of case and they only progressively appear during the 20th century. 
2. Extraordinary (EXT) floods: Fluvial Floods. Water level clearly overflowing the river bank. Moderate damage in towns. Disturbances in quotidian activities from the presence of water in urban and rural areas.

3. Catastrophic (CAT) floods: Fluvial Floods. Water level greatly overflows the river bank. Very severe damage. Permanent infrastructures (bridges, walls, mills, buildings, and dams) are partially or completely destroyed. Strong impacts require much time for reconstructions.

The obtained series are normalized with their respective standard deviations in order to evaluate their anomalies and create regional clusters.

\subsection{Sources of information}

The information collected for the present work concerns river systems that are still in the natural regime or where diverse structural interventions have been implemented. For each basin, the social contexts and historical evolution have also been studied in order to understand the different situations. In this way, the natural climatic variability is correctly assessed in terms of the seasonal distribution of events, their interannual variability, and their frequency. It is also possible to assess the contribution of the human factor in the frequency and severity of flood events, either in terms of their proliferation or their decrease.

The information sources we used also fulfill the criterion of providing the greatest possible diversity; and they are based mainly on primary and secondary sources (Barriendos et al., 2014, p. 11). The primary sources comprise administrative documentation from local authorities and reports in the general press, both of which are contemporary with the facts. Secondary sources are mostly local historiography. These printed sources are in turn based on primary sources, so their reliability is acceptable. Finally, we also consulted tertiary sources that were based on secondary sources. Their reliability is low and the amount of detailed information is low. These are usually reports or information catalogs created by public institutions, and they are very far from the original documentary sources.

The origin of the information is sufficiently homogeneous to offer reliability and consistency for generating flood timelines. The same types of sources are used in the different chronologies, regardless of the size of the population. For example, the administrative documentary sources from which most of the original information originates are generated under the same criteria of content and formality as for any population.

The locations where the information is generated also show considerable homogeneity over time. The documentary sources themselves almost always generate information about floods in urban areas and basic infrastructures; thus, their evolution over time is minimal. The physical conditions of the river sections where the information is generated experience limited evolution, considering that a good part of the chronologies begin between the 14th and 16th centuries. Of course, the demographic evolution and interventions in the river system vary greatly, and these factors point toward possible future research on discriminating between natural and anthropic processes, as well as their interactions with each other.

\subsection{Chronological series}

The results obtained in successive works are shown in Table 3. The table proves not only that the documentary and bibliographic sources contain a large amount of information, but also that the potential for future research is evident. Our intensification of the research has led to three key improvements that justify this update: 
a) The number of floods increases from 1060 to 2467 (232.7\%).

b) The number of available series has increased from 23 to 27 (17.4\%), a modest quantitative improvement but one that requires significant material effort.

c) A new classification has been created for flood cases that - after cross-checking - we have detected to be errors or false cases. 12 spurious floods have been found, and they account for $1.13 \%$ of the cases in the previous chronology. These cases are counted but are obviously isolated and excluded from analysis in the present work.

When comparing the initial chronologies (Barriendos and Rodrigo, 2006) with the present work (see Table 4), the flood cases increase from 1422 to 2874 for the whole of Spanish basins, $202.1 \%$.

18 flood series have been selected (see Table 5 and Fig. 1) from $36^{\circ}$ to $41^{\circ} \mathrm{N}$, and from $2^{\circ} 49^{\prime} \mathrm{E}$ to $4^{\circ} 25^{\prime} \mathrm{W}$. The locations where the series are obtained are situated at the midcourse or close to the mouths of the respective rivers, with the exception of two towns (Caravaca and La Seu) that are closer to the headwaters at an altitude of above $600 \mathrm{~m}$. Compared to previous works, 14 series have been substantially improved; 2 series maintain the same results; and 2 series are new (Ebro River in Zaragoza, Argos River in Caravaca).

The chronologies cover the so-called Little Ice Age and the current warming episode. Half of the series begin in the 14th century (9/18), and most of them are already available from the 17 th century (14/18). The final part of the series shows some differences. The hydraulic infrastructures have modified the overflow processes in some of the locations and recent information is consequently not very useful. However, the problems linked to increased exposure over the most recent decades (Pérez-Morales, et al., 2018) necessitate that future research should focus on studying new processes such as "in situ" floods or pluvial floods generated by a densified urban landscape and its associated infrastructures. Overall, the series of floods cover 715 years, from 1301 to 2016.

\subsection{Methodological aspects}

Studying the flood chronologies of specific locations in recent years has offered a reasonable capacity for identifying patterns of climatic variability as well as for identifying different external forcing factors. However, the path of improvement in developing this methodological approach appears to be coming to an end. The impossibility of developing new and improved elements of analysis underscores the need for a new methodological approach.

The main limitation lies in obtaining information from specific locations where the fluvial system operates in a wide area with many intervening elements and factors. If the available information is also dispersed throughout the river basin, it seems to be more useful to collect all the available information for reconstructing a complete event. It is no longer just a matter of recording floods and specific overflows, but also of compiling testimonies that allow us to know the precipitation patterns that cause the fluvial response, as well as the conditions of precipitation, the increase in flows, and the saturation of the soil in an antecedent period, as suggested by previous research (Wetter et al., 2011). The methodological approaches and work criteria were previously proposed (Barriendos et al., 2014), and we are now working along these lines to create a large database for the Spanish Mediterranean coast. The variety and quality of results that can be obtained will allow new developments in hydrological and hydraulic reconstruction, as has been established in other European areas (Elleder et al., 2012) and in the study area itself (Thorndycraft et al., 2006; Balasch et al., 2019). 


\section{Results. Temporal analysis}

\subsection{Local results}

The study of flood series within a local framework provides information on general climate variability as well as various local-scale behaviors. The orography and drainage network of the fluvial systems affect the frequency and magnitude of the flood episodes. Human factors also affect these localisms, since the location of urban centers generates different degrees of exposure and vulnerability to flooding, according to different historical contexts.

On the other hand, these local-scale factors can occur intermittently over time at limited and irregular durations, thus generating behaviors that require very detailed investigation. Some examples may be changes in the configuration of riverbeds or land uses that alter surface hydrology, hydraulic infrastructures with disparate results, highly exposed constructions, and vulnerable activities.

The purpose of this paper is not to arrive at a detailed analysis of the circumstances for each reconstructed series of floods. Therefore, the following sections report on a regional scale analysis. However, it can be useful to observe local series at the methodological level in order to detect any technical, natural or social events that may cause spurious biases, tendencies or behaviors.

The results for each location (Figs. 2-6) describe very long durations of behavior over time and with reasonable homogeneity. Most series of catastrophic floods show patterned behavior without trends or with the values out of range. Extraordinary floods present a different behavior. Until the middle of the 19th century, the fluctuations are similar to those of catastrophic floods. From the 19th century, some series show a positive trend that becomes permanent during the 20th century. Other series record that process as more accentuated and centered within the 20th century.

\subsection{Climatic variability patterns}

Relying on the geographical extension covered by the series of reconstructed floods, we propose a regionalization that includes between 2 and 5 series in order to more consistently characterize the climatic variability patterns that have occurred in recent centuries:

- Northern rivers (4): Ter / Onyar, Besòs, Llobregat and Francolí.

- Ephemeral coastal rivers (4): Capaspre, Sobirans, Cirera, Rieras de Barcelona.

- Segre-Ebro system (5): Segre in La Seu d'Urgell, Balaguer and Lleida. Ebro in Zaragoza and Tortosa.

- Central rivers (2): Turia, Júcar.

- Southern rivers (3): Segura, Argos, Guadalmedina.

The averaged results allow avoiding local scale incidents and to highlight behaviors that are linked most to general climatic variability.

\subsubsection{Northern rivers}

The behavior of catastrophic floods shows close to average values during long periods of the series, such as during the 15 th and first half of the 16th centuries, the mid-17th century to the mid-18th, and the entire 20th century (Fig. 7). However, there appear three oscillations of 4060 years of outstanding duration. During the 14th century, behavior of pronounced frequency is observed, but the lack of sufficient information does not allow us to go further. The most 
obvious oscillations occur in the periods $1570-1620,1760-1800$ and $1840-1880$. These are known behaviors (Barriendos et al., 1998; Llasat et al., 2005; Barrera-Escoda et al., 2006) that, despite the strong increase in registered cases, maintain their presence. The three oscillations have a similar magnitude, except for the intermediate one that is somewhat lower. In all cases, these oscillations are shown with two subpeaks.

Extraordinary floods have a totally different behavior (Fig. 7). Their values remain below the average, with a slight increase until the mid-18th century. From that moment on, a short but severe sequence of oscillations occurs with an increasing tendency.

\subsubsection{Ephemeral coastal rivers}

The small rivers near the coast, with a non-permanent flow, present a behavior almost identical to the permanent rivers (Fig. 7). The dimensions and configuration of the basin do not seem to influence the processes that affect the frequency and severity of the atmospheric events that cause the floods. These are river courses without regulation and that interact heavily with permanently populated areas.

Catastrophic floods for these rivers have a greater number of oscillations with different magnitudes and durations than those of northern rivers (Fig. 7). The most severe totally coincide with the three that were already detected in the series for northern rivers.

Regarding the extraordinary floods (Fig. 7), their behavior is similar to that of the northern rivers; but they started later, at the end of the 19th century, and their tendency is very marked and of great magnitude.

\subsubsection{Segre-Ebro system}

The catastrophic floods of this system present numerous oscillations (Fig. 7). The three Little Ice Age oscillations in the previous regions appear in the same way. Two smaller oscillations are now added to the mid-16th century and the mid-15th century. Also, two relevant oscillations occur at the beginning and end of the 14th century, which may correspond to the initial part of the Little Ice Age. These oscillations are perceptible despite the limited information available for the 14th century: 42 floods, which represent $1.85 \%$ of the total analyzed floods.

A remarkable period of calm and normality appears from the mid-17th century to the mid-18th century, and another in the 20th century, which is probably linked to the construction of reservoirs.

The extraordinary floods show very moderate behavior between the 14th and 18th centuries, although with multiple brief anomalies (Fig. 7). During the late 18th and mid-19th century, it is remarkable that duration and magnitude occur simultaneously for both type of floods (extraordinary and catastrophic). The frequency of these floods is already relatively high during the 20th century, as is the case in the regions already analyzed.

\subsubsection{Central rivers}

The catastrophic floods of the Turia and Júcar rivers (Fig. 7) show a unique integration of previously known aspects in the northern series and those of the Segre-Ebro system. Until the 16th century, frequent low intensity oscillations are observed. The three oscillations already observed appear with similar durations and magnitudes. Perhaps that of 1570-1620 is longer, with one main peak at the beginning and two secondary ones until 1640.

The novelty is the appearance of a fourth oscillation with similar characteristics during the second half of the 17th century. At first glance, it can be understood that the driving factors present in the northern series also exist in this area, in addition to other different atmospheric processes, related to meridional dynamics of the atmospheric circulation, affecting the flood regime of the area. 
The extraordinary floods in this region (Fig. 7) present more peaks of frequency than other regions. Their quantity is similar to that of catastrophic floods, so it can be considered that the Turia and Júcar are rivers that show a greater hydrometeorological variability with respect to the northern ones. Its temporal distribution until the mid-16th century is similar to that of other cases. However, three very notable oscillations accompany those recorded for catastrophic floods: one that is almost synchronous between the 16th and 17th centuries; another during the second half of the 18th century, during which catastrophic floods occur; and a third in the mid-19th century, which coincides with the catastrophic floods. During the 20th century, they tend to decrease, although a certain positive upturn has occurred in recent years.

\subsubsection{Southem rivers}

The catastrophic floods in this region (Fig. 7) present a frequency pattern very different from that of the previously described regions. No obvious oscillations are perceived, but a succession of moderate oscillations are regularly distributed over time: in the mid-15th century, the first half of the 16th century, the first half of the 17th century, the second half of the 17th century, and the end of the 19th century. Contrary to the other regions, catastrophic floods are also relatively frequent during the 20th century.

The extraordinary floods (Fig. 7) show very moderate behavior except during an oscillation in the second half of the 15th century and another in the second half of the 19th century. The current trend towards a strong increase in this type of flooding is similar to that detected in a large part of the studied regions.

\subsection{Population increase and flood trends}

A key issue for societies adapting to flood risk is centered on the relationships between increased exposure, increased vulnerability and trends over time, specifically in terms of the frequency and intensity of floods (Jongman et al., 2015). This relationship is giving rise to an intense scientific debate on the need to normalize the impact of floods (Barredo, 2009). The final goal of these studies is focused on knowing to what extent the variability of floods is caused by climate variability or by changes in the social systems (Paprotny et al., 2018). In the Iberian Peninsula, the normalised flood impacts over the period 1970-2010 eliminates the positive trend on flood damages over time, indicating a general decrease on flood hazards, whereas exposure and vulnerability increased the reported flood looses (Benito and Machado, 2012).

In order to approach this problem, we have related flood rates to population rates over time, to which end we have obtained annual population series (from 1857 to the present) for the 18 studied locations. The population data come from the National Population Censuses of 1857, 1860, 1877, 1887, 1897, 1900, 1910, 1920, 1930, 1940, 1950, 1960, 1970, 1981, 1991, 2001, 2011, and also from the Municipal Register of Inhabitants of 2016. All the data have been obtained from the official reference source of the Spanish State: The Statistical National Institute (INE, 2018). The length of the periods between two censuses is variable, so we have calculated the annual average population increase (decrease) between two censuses in order to assign annual population values for each location. Finally, for each year of the intercensal period we add (subtract) as many annual increases (decreases) as years that have passed between the first census and the target year. This procedure results in some average values for population increases of $709 \%$ in all the locations. In this way, the population has gone from 681,449 inhabitants in 1875 to 4,829,137 inhabitants in 2016. The population increase range varies between the minimum in Tortosa $(135 \%)$ to the maximum in Sant Adrià del Besòs 
$(10,993 \%)$. These differences can be explained by different economic dynamics in three groups of locations:

a) Small cities far from the coast that, unlike the other locations, were not integrated into the dynamics of the urban boom prior to the economic crisis of 2008 and the explosion of "Sun and Beach" tourism (La Seu d'Urgell, Balaguer, Alzira, Tortosa and Caravaca).

b) Inland cities that constitute either their regional capital (Murcia and Zaragoza) or provincial capital (Girona and Lleida), by which highly concentrated services, trade flows and financial flows fueled high socioeconomic dynamism and urban development over recent decades.

c) Coastal areas constitute a group that includes regional capitals (Barcelona and Valencia), provincial capitals (Tarragona and Malaga), purely tourist municipalities (Calella and Arenys de Mar), and the metropolitan area of Barcelona (Mataró, El Prat and Sant Adrià), all of which are very distinct from one another. In the case of the coastal capital cities, their status underlies a concentration of services and capital flows that fueled the dynamism of coastal tourism having grown to maximum levels since the nineteen-sixties.

The differences between groups are clearly reflected in population growth. While the Group A cities grew by $212 \%$ between 1857 and 2016, the Group B cities grew by $716 \%$ and Group C by $779 \%$.

However, assigning exposure data (population) and contrasting it with the long-term flood series presents some problems: the population data are scattered and heterogeneous; the climate and flood variability presents a non-linear spatiotemporal variability pattern; finally, the structural flood risk mitigation measures (dams, bypass channels, storm water retention reservoirs, etc.) have undoubtedly contributed to changing the natural hydrological behavior of rivers (López-Martínez et al., 2017).

Taking these considerations into account, we analyze the data obtained. The first conclusion reached is that at the time when a flood occurs, the affected population is higher than in the past (Fig. 8). In some towns such as Mataró, Barcelona, Sant Adrià and Málaga, this fact is especially evident. In other words, there has been a significant increase in the population affected by floods. This increase is greater in the metropolitan area of Barcelona and other major urban centers that have experienced more recent tourist development, such as Malaga.

Nevertheless, the increase in the average of the population affected by each event does not necessarily imply that there is a growing temporary trend in the population affected by floods, because the population can increase at the same time as the frequency of floods is reduced. To analyze this fact, we have conducted a temporal trend analysis for both the frequency of floods and for the affected population. In both cases, we have considered data from 1857 onwards. Each locality and each flood intensity level have been analyzed (see Table 6) and, depending on the area considered, the results show increases or decreases in the temporal trend of the floods. These increases and decreases are due partially to, respectively, the presence and absence of adaptation strategies against flood risk. In general, four types of locations are detected, depending on the flood trends from 1857 to the present:

1. Inland cities where there has been an increase in the frequency of floods and/or the population affected by floods (Girona and La Seu de Urgell). This situation reveals that the pertinent adaptation measures have not been carried out, which is even more serious insofar as the affected population in these cities has increased at a lower intensity than for the whole area. 
2. Inland cities where the situation remains unchanged (Balaguer and Lleida) or improved (Caravaca). This situation may reveal a correct adaptation strategy to floods, with an added benefit of lower growth in the exposed population.

3. Coastal cities where there has been an increase both in frequency and in the population affected by floods (Malaga, Tarragona, Mataró, Calella and Arenys de Mar). This situation indicates that the development implicit in the economic model based on housing construction and coastal tourism has not been accompanied by a strategy for mitigating the danger of flooding.

4. Cities along the banks of large rivers in areas with strong investment in structural measures against floods, which have thus managed to control or reduce the frequency and the population affected by floods (Zaragoza and Tortosa in the Ebro River basin, Murcia in the Segura River basin, El Prat in the Llobregat River basin, Valencia in the Turia River basin, and finally Alzira in the Jucar River basin). These cities have been able to develop their economic and demographic models without increasing the risk of flooding for their population.

Additionally, some situations cannot be added to any of the above patterns. On the one hand, we have the town of Sant Adrià, which is integrated into the city of Barcelona's demographic dynamics and, despite its high demographic and urban dynamism, the flood situation remains stable. In Barcelona on the other hand, the affected population and frequency of extraordinary floods have increased, but the frequency of catastrophic floods has decreased. The case of Barcelona is paradigmatic because it is the main city in the study area and the one that is the best example of demographic and urban growth. In spite of this, its growth process correlates with investment in defense infrastructures which has allowed for a reduction in the frequency of catastrophic floods. The case of Sant Adrià is even clearer in this respect, as investments in flood defense measures have allowed this city with the highest population growth in the study area to keep the flood risk stable.

Regarding the frequency of floods, the situation is positive in that catastrophic floods have not increased anywhere. In fact, this type of flood has even decreased in some places (Barcelona, Alzira, Caravaca and Tortosa). However, extraordinary floods present a totally different evolution, as they increase in $40 \%$ of the locations analyzed (Barcelona and Málaga are the largest cities where this increase occurs). Since extraordinary floods constitute the majority of the reconstructed floods, the trend in total frequency of floods also increases in some of these locations. In this respect, floods are becoming more frequent in the northeast of Catalonia and in the city of Málaga.

If we consider the population affected by floods, these same patterns are detected. However, what is more worrying is that new places are detected where the situation is worse. In this regard, only three places experience a decrease in the population affected by catastrophic floods (Alzira, Caravaca and Tortosa). The locations where the population affected by extraordinary floods increases coincide with the locations where the frequency of extraordinary floods increases, but adding La Seu d'Urgell. In Barcelona, as in Málaga, Girona, Calella, Arenys de Mar and Mataró, there has been an increase in the population affected by floods. In general, the whole study area has seen an increase in the population affected by extraordinary floods.

It is worth highlighting the case of the city of Valencia, where flood protection measures have reduced the extraordinary floods both in terms of both frequency and affected population. Similarly, in other cities where higher structural flood risk mitigation measures have been implemented, the trends are stable or negative (as in the cases of Alzira in the Jucar River and Tortosa in the Ebro River). 


\section{Discussion}

The reconstructed chronologies show identifiable and interpretable behaviors, giving the impression that historical flood evidences can be compared to natural proxy-data, such as those obtained in lakes, rivers and more recently dendrogeomorphological sediments (Romero-Viana et al., 2011; Nieto-Moreno et al., 2013; Barreiro-Lostres, et al., 2014; Ballesteros-Cánovas et al., 2015; Corella et al., 2016; Schulte et al., 2019).

\subsection{Flood temporal patterns}

The compilation of flood series in very long periods allows us to observe patterns of climatic behavior in a hydrometeorological point of view. The results obtained in the present work show the characteristics of the two different types of floods (catastrophic and extraordinary), as well as their variations over time (Fig. 9).

In all the regional series and in the final summary, the catastrophic floods seem to demonstrate behavior linked to the climatic variability and expressed by patterns of atmospheric circulation that favor torrential and persistent rain events, which altogether are necessary for the fluvial overflows in the Mediterranean basin. There are different oscillations corresponding to the climatic conditions during the Little Ice Age (Oliva et al., 2018). The most severe, with indexes of $\geq 0.15$ in the 31-year-old Gaussian filter are:
a) $\quad 1324-1328(5$-year duration)
b) $\quad 1580-1620$ (41 years)
c) $1774-1793$ (20 years)
d) $\quad 1843-1877(35$ years $)$

The beginning and the end of the series of catastrophic floods deserve some attention. During the first years, the series shows a brief but abrupt oscillation with values of $\geq 0.15$ in the aforementioned index between the years 1324 and 1328. This may be the beginning of the Little Ice Age climatic episode in the study area. Even though the documentary sources for that time are scarce and the exposed populations near the rivers were of too modest in size to register these events in any appreciable fashion, the oscillation is evident and of considerable magnitude.

The other three climatic oscillations that are observed in the Little Ice Age present similar magnitudes. Those of 1580-1620 and 1843-1877 are of a similar duration but their behavior is also identical: a simple increase in the frequency of floods. However, the oscillation of 1774-1793 is shorter, with a less intense increase in flood frequency, and it is quite singular in that it coincides with a strong increase in droughts, as if responding to some unique anomaly in the Little Ice Age (Barriendos et al., 2003). Its temporal distribution also indicates its singularity: between oscillations a), b) and d), there are 253 and 224 years of separation. Oscillation c) is asymmetric, with 155 and 51 years of distance from the previous and subsequent oscillations.

The recent period corresponding to the 20th century shows a decreasing trend with respect to the end of the Little Ice Age. This behavior can be due to two factors that are not incompatible with each other: a) a reduction in the frequency of extreme hydrometeorological events related to a new climatic episode after the Little Ice Age; b) growing human interventions of large hydraulic infraestructures that reduce the risk of catastrophic floods, either by eliminating them completely or by transforming them into extraordinary floods or ordinary floods. Accurately assessing the contribution of one factor or another would require 
a detailed investigation of each reconstructed local series. Given the fact that some locations have infrastructures and others are still in a natural regime, we can presume that this would be a complex investigation due to interactions between the natural and human dimensions.

In summary, this type of flooding has a natural behavior and no recent trends that can be linked to human-induced climate change, an aspect that would coincide with other results at a more general scale (Brázdil et al., 2006).

Extraordinary floods present a long period of synchronicity with catastrophic floods. Their behavior is consistent with the most severe floods. Even the three oscillations of the 16th-19th centuries are also recorded with minimal but positive deviations in the case of extraordinary floods.

However, one fact also contributes to changing the behavior of extraordinary floods throughout the 20th century: at the end of the Little Ice Age, the recorded high frequencies do not decrease but instead maintain high values while even increasing. In the whole series of more than 700 years, this is the first and only time that this behavior is observed. The divergence of trends between catastrophic and extraordinary floods occurs exactly in 1904. This can be considered a new phase in the flood regime on the Spanish Mediterranean coast.

The general interpretation of the results allows us to identify a very obvious driving force: the hydrometeorological atmospheric processes that cause torrential and persistent rains. On the other hand, the following two general factors cause substantial changes and trends in the frequency of flood events. 1) Natural climate variability affects the occurrence of catastrophic floods in oscillations of 20 to 40 years with very severe effects, leaving long periods of low activity. A similar pattern is shown in the extraordinary floods, but the occurrence of large oscillations is not evident. 2) Human activities also affect the frequency of floods. It seems that actively constructing dams and dykes reduced catastrophic floods in the recent period throughout the 20th century. This may be ascribed to directly eliminating catastrophic events, but it can also be interpreted that this type of event was simply transferred to unpopulated areas, which would explain the increase in extraordinary flood events in such a way that the social impact would result in a reduction in the severity of the events.

However, population growth and the coastal urban boom that began in the 1960s have led to a statistically significant increase in extraordinary floods from the mid-19th century to the present. In this case, the trends are pronounced during the 20th century and present in the coastal areas, probably influenced by the role of tourism in urbanistic growing process initiated in the 1960s (Pérez-Morales et al., 2018). However, the greater or lesser urban and demographic growth of the analyzed cities does not reflect a perfect correlation with the greater or lesser growth of floods. In this respect, the lower vulnerability of cities (LópezMartínez, et al, 2017) and, above all, investments in flood defense infrastructures play a determining role in explaining the reduction and stabilization of floods in the analyzed locations. A large part of these advances in flood defense were produced thanks to strong investment programs and legislative changes promoted in the nineteen-eighties (OlcinaCantos, et al., 2016). In any case, defense infrastructures certainly do not ensure total defense against floods (Castillo-Rodríguez, et al., 2016; Olcina-Cantos, et al., 2016), especially when observations of the study area indicate that this type of measure generates a false sense of security, which in turn can lead to increased exposure and vulnerability in the medium term (Saurí-Pujol et al., 2001).

Additionally, there are other factors that may explain the recent changes observed. In light of an evident increase in exposure and vulnerability to floods, climate change may also intervene with an increase in heavy precipitation events (Höppe and Grimm, 2009; Coumou and Rahmstorf, 2012). This aspect cannot be delved into here because it is not included in the objectives of the work, but the results point toward the possibility of its existence and incidence. Large events with severe multiple overflows are no longer so frequent, but faster 
and more intense local precipitation multiplies the presence of events at a limited scale and of low severity. However, its low destructive capacity is compensated by high frequency and a growing tendency towards the future.

\subsection{On the reasons that explain the temporal variability of the floods}

The compilation and descriptive analysis presented here is far from able to ascertain the factors and processes that lead climatic variability to affect anomalies in the study area's flood frequency. Nevertheless, some comparisons can be made to establish future work hypotheses.

First of all, of particular interest is the coincidence between the abovementioned oscillations that increase frequency of floods and increase of length of the alpine glaciers during the Little Ice Age. This synchrony appeared in previous works (Barriendos and Martin-Vide, 1998, Llasat et al., 2005). Looking at successive studies conducted in great chronological detail on the glaciers of the Swiss Alps, we find brief moments of glacial growth precisely when the frequency of catastrophic floods increases on the Spanish Mediterranean coast (Holzhauser and Zumbühl, 1996; Pfister, 1988; Zumbühl, 1980; Zumbühl and Holzhauser, 1988). This cannot be coincidental and deserves a more detailed future investigation into the evident interactions of atmospheric circulation patterns.

The most recent research on variability patterns in atmospheric circulation focuses on the Atlantic Multidecadal Variability Index (Wang et al,, 2017, p.513). Combining its results with future research may relate this index to certain regional climate processes. At the moment, it can be observed that the index's cold phases and events coincide with the high frequency of flood oscillations on the Mediterranean coast. These cold conditions would explain the growth of alpine glaciers and the increase in torrential rainfall in the Mediterranean, because when cold air comes into contact with the humid superficial air produced by this inner sea's high water temperatures, it is inevitable that torrential rainfall events could occur at almost any moment in the year. In fact, $75-80 \%$ of the severe precipitation events are typical Mediterranean processes (local convective activity and Mediterranean cyclogenesis), which are caused or even aggravated by the presence of high cold air and humid air at the surface, while only $20-25 \%$ are caused by fronts with an Atlantic origin (Millán, 2014).

The factor that causes the most uncertainty is global warming induced by anthropic climate change. The climatic projections present an increase in temperature associated with increases in torrential rains over Northern Europe and in drought sequences across Southern Europe with strong decrease of yearly total precipitation (c. $30 \%$ of reduction). In despite of this precipitation reduction, in Southern Europe there will be an increase in torrential precipitation (Barrera-Escoda and Cunillera, 2011). In fact, this increase is detected in the series of floods in northern Europe. Others have also stated that the trends between floods and climate change do not present consistent correlations. The signs are present but the causal relationship remains to be confirmed. The challenge is complex, because when dealing with atmospheric and superficial phenomena in the study of interactions between natural and social processes, it is necessary to consider multiple aspects that are difficult to identify, much less ascertain their contributions (Füssel, 2012).

\section{Conclusions}

Historical hydrology is a suitable methodology for detecting and analyzing flood events over long periods of time. The level of knowledge is still very low, due to lack of massive access to historical archives. If one wants to conduct a detailed study on the uncertainty of river system 
behaviors, substantial efforts must be made toward collecting original information that is more comprehensive and of better quality.

We have presented 18 flood series in different locations along the Spanish Mediterranean coast, all of them covering a period of 715 years. Following previous works, the floods analyzed here are catastrophic and extraordinary, depending on the damage they caused.

The most severe floods are known as catastrophic, and they show oscillations of 40-60 years during the Little Ice Age. These coincide with cold phases, which disappear during the subsequent period. It remains to be investigated the extent to which the current situation is related to a naturally occurring low frequency of floods or to effective human interventions for reducing the risk of flooding.

There is a certain difference in the behavior of catastrophic floods in the series of northern versus southern floods. The northern ones seem to be linked to an atmospheric dynamic of cold episodes, which is consistent with the synchronous pulses of advancing Alpine glaciers. These oscillations are not perceived so clearly in the southern series and, instead, oscillations appear with a different temporality.

This complexity is due to the Western Mediterranean being located in a transition zone where there is a predominance of air mass circulation. An investigation in greater detail may be relevant for better understanding future atmospheric dynamics scenarios if climate change conditions increase.

The influence on both minor and extraordinary floods by human activity in river basins clearly appears from the end of the 19th century. Oscillations no longer appear over time, but a permanent positive trend is evident. This is especially intense in the series of coastal locations, where there is greater demographic growth and tourism activity. Future research can delve into how extensively these human activities are related to extraordinary floods.

In analyzing the adaptive response of societies to floods over the last 150 years, the study area highlights some noteworthy issues. On the one hand, the large infrastructural defense structures against floods have caused a decrease in the risk of flooding in some locations, which materializes as decreases in both the number of events and the affected population. On the other hand, a disturbing rise in the frequency of extraordinary floods has occurred in coastal locations since the mid-19th century to the present. This increase becomes magnified if we consider the population exposed to flooding. In other words, there has been a notable increase in the population affected by extraordinary floods. Without proper planning, the scenario for coastal populations will be difficult when adapting to the risk of flooding.

\section{Author contributions}

MB prepared most of flood series for Catalonia and improved upon previous flood series for the area. In addition, he handled the database organization, statistical treatment, graphic production, the coordination and integration of texts, and preparation of the tables and figures.

SG-G prepared the flood series for the cities of Murcia and Caravaca. He also contributed a social factor analysis for all flood chronologies.

DP lent support in preparing flood data series and conducting a meteorological assessment to define flood cases and flood events. He revised the entire redaction and integration process of the manuscript, as well as a final revision of the whole text.

JT contributed to preparing the Segre and Ebro flood data series, as well as the cartographic basis.

AP-M contributed to preparing the flood series for the cities of Murcia and Caravaca.

AA prepared the flood series for the cities of Valencia and Alzira. 
JC prepared the flood series for Tortosa city. He also verified and improved on the data for the Segre-Ebro fluvial system.

JCB prepared the flood series for Zaragoza city and improved the Segre chronologies.

XC collaborated with JCB for the Zaragoza city flood series and the Segre chronologies.

JM collaborated with DP on the meteorological assessment.

JLR-B collaborated with JCB on the flood series for Zaragoza city.

\section{Acknowledgements}

This work has been partially supported by the Spanish Ministry of Economy and Innovation (CGL2016-75996-R). SG-G acknowledges the support of the Spanish Ministry of Science, Innovation and Universities through "Juan de la Cierva-Incorporación" grant (IJCI-201629016). AA acknowledges the support of the Spanish Ministry of Economy and Innovation (HAR2017-82810-P). MB acknowledges the support of the Research Group of Generalitat de Catalunya "Paleogeoecologia, Riscs Naturals i Gestió Ambiental (PaleoRisk)" (2017SGR1106).

We would also like to acknowledge the data and support provided by the Servei Meteorològic de Catalunya and the Institut Cartogràfic i Geològic de Catalunya. 


\section{References}

Addinsoft, S. A., 2018. XLSTAT software. [online] Available at: http:/www.xlstat.com/es/ [Accessed 17 Sep. 2018].

Alberola, A. 2010. Quan la pluja no sap ploure. Sequeres i riuades al País Valencià en l'Edat Moderna, Publicacions de la Universitat de València, València, 251 p.

Alberola, A., 2017. Sécheresses et inondations dans le bassin mediterranéen espagnol aux XVIe et XVIIe siècles. Réflexions au sujet des terres valencianes. In: Alberola, A. (ed.): Riesgo, desastre y miedo en la península Ibérica y México durante la Edad Moderna, Universidad de Alicante-El Colegio de Michoacán, Alicante, p.135-150.

Balasch, J.C., Pino, D., Ruiz-Bellet, J.L., Tuset, J., Barriendos, M., Castelltort, X., Peña, J.C., 2019. The extreme floods in the Ebro basin since 1600 CE. Sci. Total Environ., 646, 645-660, doi:10.1016/j.scitotenv.2018.07.325.

Ballesteros-Cánovas, J.A., Stoffel, M., St George, S., Hirschboeck, K., 2015. A review of flood records from tree rings. PPG: Earth and Environment, 39, 794-816, doi:10.1177/0309133315608758.

Barredo, J.I., 2009. Normalised flood losses in Europe: 1970-2006. Nat. Hazards Earth Syst. Sci., 9, 97-104, doi:10.5194/nhess-9-97-2009.

Barreiro-Lostres, F., Moreno, A., Giralt, S., Caballero, M., Valero-Garcés, B., 2014. Climate, palaeohydrology and land use change in the Central Iberian Range over the last 6kyr: The La Parra Lake record. Holocene, 24, 1177-1192, doi:10.1177/0959683614540960.

Barrera-Escoda, A., Llasat, M.C., Barriendos, M., 2006. Estimation of extreme flash flood evolution in Barcelona County from 1351 to 2005. Nat. Hazards Earth Syst. Sci., 6, 505-518, doi:10.5194/nhess-6-505-2006.

Barrera-Escoda, A., Cunillera, J. 2011. Primer informe sobre la generació d'escenaris climàtics regionalitzats per a Catalunya durant el segle XXI. Servei Meteorològic de Catalunya, Barcelona, 96 p. Available at: www.meteo.cat, http://staticm.meteo.cat/wordpressweb/wp-content/uploads/2014/11/19092102/informe_escenaris_SMCJUN2011.pdf.

Barrera-Escoda, A., Llasat, M.C. 2015. Evolving flood patterns in a Mediterranean region (1301-2012) and climatic factors - the case of Catalonia. Hydrol. Earth Syst. Sci., 19, 465483, doi:10.5194/hess-19-465-2015.

Barriendos, M., Martin-Vide, J., 1998. Secular Climatic Oscillations as Indicated by Catastrophic Floods in the Spanish Mediterranean Coastal Area (14th-19th Centuries). Clim. Change, 38, 473491, doi:10.1023/a:1005343828552.

Barriendos, M., Llasat, M.C., 2003. The Case of the 'Maldá' Anomaly in the Western Mediterranean Basin (AD 1760-1800): An Example of a Strong Climatic Variability. Clim. Change, 61, 191-216, doi:10.1023/a:1026327613698.

Barriendos, M., Rodrigo, F.S., 2006. Study on historical flood events of Spanish rivers using documentary data. Hydrolog. Sci. J., 51, 765-783, doi:10.1623/hysj.51.5.765.

Barriendos, M., Ruiz-Bellet, J.L., Tuset, J., Mazón, J., Balasch, J.C., Pino, D., Ayala, J.L., 2014. The 'Prediflood' database of historical floods in Catalonia (NE Iberian Peninsula) AD 1035-2013, and its potential applications in flood analysis. Hydrol. Earth Syst. Sci., 18, 1-17, doi:10.5194/hess-18-1-2014.

Benito, G., and Machado, M. J., 2012. Floods in the Iberian Peninsula. In: Kundzewicz Z.W. ed. Changes of Flood Risk in Europe IAHS Press and CRC Press/Balkema, IAHS Special Publication 10, 372-383.

Brázdil, R., Glaser, R., Pfister, C., Antoine, J.M., Barriendos, M., Camuffo, D., Deutsch, M., Enzi, S., Guidoboni, E., Rodrigo, F.S., 1999. Flood events of selected rivers of Europe in the Sixteenth Century. Clim. Change, 43, 239-285, doi:10.1023/A:1005550401857. 
Brázdil, R., Kundzewicz, Z.W., Benito, G., 2006. Historical hydrology for studying flood risk in Europe. Hydrolog. Sci. J., 51, 739-764, doi:10.1623/hysj.51.5.739.

Castillo-Rodríguez, J. T., Escuder Bueno, I., Perales Momparler, S., Porta-Sancho, J. R., 2016. Enhancing local action planning through quantitative flood risk analysis: a case study in Spain. Nat. Hazards Earth Syst. Sci., 16(7), 1699-1718, doi:10.5194/nhess-16-1699-2016ss16-1699-2016.

Corella, J.P., Valero-Garcés, B.L., Vicente-Serrano, S.M., Brauer, A., Benito, G., 2016. Three millennia of heavy rainfalls in Western Mediterranean: frequency, seasonality and atmospheric drivers. Sci. Rep., 6, 38206, doi:10.1038/srep38206, 11 p.

Coumou, D., Rahmstorf, S., 2012. A decade of weather extremes. Nat. Clim. Change, 2 , 491496, doi:10.1038/nclimate1452.

CRED (Centre for Research on the Epidemiology of Disasters), 2009. Emergency Events Database (EM-DAT). School of Public Health, Université Catholique de Louvain, Brussels. Available at: http://www.emdat.be/.

Díez-Herrero, A., Ballesteros-Cánovas, J.A., Bodoque, J.M., Ruiz-Villanueva, V., 2013a. A new methodological protocol for the use of dendrogeomorphological data in flood risk analysis. Hydrol. Res., 44, 234-247, doi:10.2166/nh.2012.154.

Díez-Herrero, A., Ballesteros, J.A., Ruiz-Villanueva, V., Bodoque, J.M., 2013b. A review of dendrogeomorphological research applied to flood risk analysis in Spain. Geomorphology, 196, 211-220, doi:10.1016/j.geomorph.2012.11.028.

Elleder, L., Herget, J., Roggenkamp, T., Nießen, A., 2012. Historic floods in the city of Prague - a reconstruction of peak discharges for 1481-1825 based on documentary sources. Hydrol. Res., 44, 202-214, doi:10.2166/nh.2012.161.

Füssel, H.M. (coord.), 2012. Climate change, impacts and vulnerability in Europe. An indicator-based report. European Environment Agency, Copenhagen, doi:10.2800/66071, 2012.

García-Torres, A., 2015. Riesgo natural, extremismo climático y desastre en tierras meridionales valencianas durante el siglo XVIII, $\mathrm{PhD}$ Thesis, Department of Medieval History, Modern History and Historiographic Sciences and Techniques, Universidad de Alicante, Alicante, $517 \mathrm{p}$.

García-Torres, A., 2016. Sequías y riadas durante la anomalía Maldá en la fachada mediterránea española: una aproximación al territorio del sur alicantino, 1760-1800. In: Arrioja Díaz-Viruell, L. A., Alberola, A. (eds.), Clima, desastres y convulsiones sociales en España e Hispanoamérica (ss. XVII-XX), El Colegio de Michoacán-Universidad de Alicante, Michoacán, p. 157-178.

Gil-Guirado, S. 2013. Reconstrucción climática histórica y análisis evolutivo de la vulnerabilidad y adaptación a las sequías e inundaciones en la cuenca del Segura (España) y en la cuenca del río Mendoza (Argentina), $\mathrm{PhD}$ Dissertation, Department of Geography, Universidad de Murcia, Murcia.

Glaser, R., Riemann, D., Schönbein, J., Barriendos, M., Brázdil, R., Bertolin, C., Camuffo, D., Deutsch, M., Dobrovolny, P., van Engelen, A., Enzi, S., Halickova, M., Koenig, S.J., Kotyza, O., Limanowka, D., Mackova, J., Sghedoni, M., Martin, B., Himmelsbach, I., 2010. The variability of European floods since AD 1500. Clim. Change, 101, 235-256, doi:10.1007/s10584-010-9816-7.

Glaser, R., 2012. Historische Klimatologie Mitteleuropas. In: European History Online $(E G O)$, Leibniz Institute of European History (IEG), Mainz. URL: http://www.iegego.eu/glaserr-2012-de. URN: urn:nbn:de:0159-2012091821 [2018-04-22].

Gregory, K.J., Starkel, L., Baker, V.R. (eds.), 1995. Global Continental Palaeohydrology, John Wiley and Sons, Chichester, $334 \mathrm{p}$. 
Hirsch, R.M., Slack, J.R., 1984. A nonparametric trend test for seasonal data with serial dependence. Water Resour. Res., 20, 727-732, doi:10.1029/WR020i006p00727.

Holzhauser, H., Zumbühl, H.J., 1996. To the history of the Lower Grindelwald Glacier during the last 2800 years -palaeosols, fossil wood and historical pictorial records- new results, $Z$. Geomorphol., Neue Folge, Supplementband 104, 95-127.

Höppe P., Grimm T., 2009. Rising natural catastrophe losses: what is the role of climate change? In: B. Hansjürgens, R. Antes (Eds.). Economics and management of climate change: risks, mitigation and adaptation. Springer, NY, USA, pp. 13-22.

INE, 2018. Instituto Nacional de Estadística. (Spanish Statistical Office): [online] Available at: http://www.ine.es/welcome.shtml [Accessed 15 Nov. 2018].

Jongman, B., Winsemius, H.C., Aerts, J.C., de Perez, E.C., van Aalst, M.K., Kron, W., Ward, P.J., 2015. Declining vulnerability to river floods and the global benefits of adaptation. Proc. Natl. Acad. Sci. U.S.A., 112, E2271-E2280, doi:10.1073/pnas.1414439112.

Llasat, M.C., Barriendos, M., Barrera-Escoda, A., Rigo, T., 2005. Floods in Catalonia (NE Spain) since the 14th Century. Climatological and meteorological aspects from historical documentary sources and old instrumental records. J. Hydrol., 313, 32-47, doi:10.1016/j.jhydrol.2005.02.004.

López-Martínez, F., Gil-Guirado, S., Pérez-Morales, A., 2017. Who can you trust? Implications of institutional vulnerability in flood exposure along the Spanish Mediterranean coast. Environ. Sci. Policy, 76, 29-39, doi:10.1016/j.envsci.2017.06.004.

Macdonald, N., Sangster, H., 2017. High-magnitude flooding across Britain since AD 1750. Hydrol. Earth Syst. Sci., 21, 1631-1650, doi:10.5194/hess-21-1631-2017.

Millán, M., 2014. Extreme hydrometeorological events and climate change predictions in Europe. J. Hydrol., 518, 206-224, doi:10.1016/j.jhyd rol.2013.12.041.

Nieto-Moreno, V., Martinez-Ruiz, F., Giralt, S., Gallego-Torres, D., García-Orellana, J., Masqué, P., Ortega-Huertas, M., 2013. Climate imprints during the 'Medieval Climate Anomaly' and the 'Little Ice Age' in marine records from the Alboran Sea basin. Holocene, 23, 1227-1237, doi:10.1177/0959683613484613.

Olcina-Cantos, J., Saurí, D., Hernández, M., Ribas, A., 2016. Flood policy in Spain: a review for the period 1983-2013. Disaster Prev. Manag., 25(1), 41-58, doi:10.1108/DPM-05-20150108 .

Oliva; M., Ruiz-Fernández, J., Barriendos, M., Benito, G., Cuadrat, J.M., García-Ruiz, J.M., Giralt, S., Gómez-Ortiz; A., Hernández, A., López-Costas, O., López-Sáez, J.A., MartínezCortizas, A., Moreno, A., Prohom, M., Saz, M.A., Serrano, E., Tejedor, E., Trigo, R., ValeroGarcés, B., Vicente-Serrano, S., 2018. The Little Ice Age in Iberian mountains. Earth-Sci. Rev., 177, 175-208, doi:10.1016/j.earscirev.2017.11.010.

Paprotny, D., Sebastian, A., Morales-Nápoles, O., Jonkman, S.N., 2018. Trends in flood losses in Europe over the past 150 years. Nat. Commun., 9, 1985, doi:10.1038/s41467-01804253-1.

Pérez-Morales, A., Gil-Guirado, S., Olcina-Cantos, J., 2018. Housing bubbles and the increase of flood exposure. Failures in flood risk management on the Spanish south-eastern coast (1975-2013). J. Flood Risk Manage., 11, S302-S313, doi:10.1111/jfr3.12207.

Pfister, C., 1988. Klimageschichte der Schweiz 1525-1860. Das Klima der Schweiz von 15251860 und Seine Bedeutung in der Geschichte von Bevölkerung und Landwirtschaft, Academica Helvetica, 6, Verlag Paul Haupt, Bern.

Pino, D., Ruíz-Bellet, J.L., Balasch, J.C., Romero-León, L., Tuset, J., Barriendos, M., Mazón, J., Castelltort, X., 2016. Meteorological and hydrological analysis of major floods in NE Iberian Peninsula, J. Hydrol., 541, A, 63-89. doi: 10.1016/j.jhydrol.2016.02.008.

Roberts, N., Moreno, A., Valero-Garcés, B.L., Corella, J.P., Jones, M., Allcock, S., Woodbridge, J., Morellón, M., Luterbacher, J., Xoplaki, E., Türkeş, M., 2011. 
Palaeolimnological evidence for an east-west climate see-saw in the Mediterranean since AD 900. Glob. Planet. Chang., doi:10.1016/j.gloplacha.2011.11.002.

Romero-Viana, L., Juliá, R., Schimmel, M., Camacho, A., Vicente, E., Miracle, M.R., 2011. Reconstruction of annual winter rainfall since $\mathrm{AD} 1579$ in central-eastern Spain based on calcite laminated sediment from Lake La Cruz. Clim. Change, 107, 343-361, doi:10.1007/s10584-010-9966-7.

Ruiz-Bellet, J.L., Balasch, J.C., Tuset, J., Barriendos, M., Mazon, J., Pino, D., 2015. Historical, hydraulic, hydrological and meteorological reconstruction of 1874 Santa Tecla flash flood in Catalonia (NE Iberian Peninsula). J. Hydrol., 524, 279-295, doi:10.1016/j.jhydrol.2015.02.023.

Ruiz-Villanueva, V., Díez-Herrero, A., Bodoque, J.M., Ballesteros, J.A., Stoffel, M., 2013. Characterization of flash floods in small ungauged mountain basins of central Spain using an integrated approach. Catena, 110, 32-43, doi:10.1016/j.catena.2013.06.015.

Salinas, J.L., Kiss, A., Viglione, A., Viertl, R., Blöschl, G., 2016. A fuzzy Bayesian approach to flood frequency estimation with imprecise historical information. Water Resour. Res., 52, 21 p., doi:10.1002/2016WR019177.

Sauri-Pujol, D., Roset-Pagès, D., Ribas-Palom, A., Pujol-Caussa, P., 2001. The 'escalator effect' in flood policy: the case of the Costa Brava, Catalonia, Spain. Appl. Geogr., 21(2), 127-143, doi:10.1016/S0143-6228(01)00003-0.

Schulte, L.; Schillereff, D.; Santisteban, J.I. 2019. "Pluridisciplinary analysis and multiarchive reconstruction of paleofloods: Societal demand, challenges and progress", Glob. Planet. Change, 177, 225-238, doi:10.1016/j.gloplacha.2019.03.019

Thorndycraft, V., Barriendos, M., Benito, G., Rico, M., Casas, A., 2006. The catastrophic floods of A.D.1617 in Catalonia (NE Spain) and their climatic context. Hydrolog. Sci. J., 51, 899-912, doi:10.1623/hysj.51.5.899.

Toreti, A., Xoplaki, E., Maraun, D., Kuglitsch, F.G., Wanner, H., Luterbacher, J., 2010. Characterisation of extreme winter precipitation in Mediterranean coastal sites and associated anomalous atmospheric circulation patterns. Nat. Hazards Earth Syst. Sci., 10, 1037-1050, doi:10.5194/nhess-10-1037-2010.

Wang, J., Yang, B., Ljungqvist, F.C., Luterbacher, J., Osborn, T.J., Briffa, K.R., Zorita, E., 2017. Internal and external forcing of multidecadal Atlantic climate variability over the past 1,200 years. Nat. Geosci., 10, July 2017, 512-518, doi:10.1038/NGEO2962.

Wetter, O., Pfister, C., Weingartner, R., Luterbacher, J., Reist, T., Trösch, J., 2011. The largest floods in the High Rhine basin since 1268 assessed from documentary and instrumental evidence. Hydrolog. Sci. J., 56, 733-758, doi:10.1080/02626667.2011.583613.

Zumbühl, H.J., 1980. Die Schwankungen der Grindelwaldgletscher in den historischen Bildund Schriftquellen des 12.-19. Jarhunderts. Ein Beitrag zur Gletschergeschichte und Erforschung des Alpenraumes, Denkschrift Schweiz, Naturforschende Gesselschaft, 92.

Zumbühl, H.J., Holzhauser, H., 1988. Alpengletscher in der Kleinen Eiszeit, Die Alpen, Sonderheft zum 125 jährigen Jubiläum des SAC. 
Table 1. Basic characteristics of the analyzed rivers in the historical flood series

\begin{tabular}{|c|c|c|c|c|}
\hline River (north to south) & $\begin{array}{c}\text { Length } \\
(\mathbf{k m})\end{array}$ & $\begin{array}{l}\text { Catchment } \\
\text { area }\left(\mathbf{k m}^{2}\right)\end{array}$ & $\begin{array}{l}\text { Water source area } \\
\text { Altitude (m.a.s.l.) }\end{array}$ & $\begin{array}{l}\text { Mean annual } \\
\text { runoff }\left(\mathrm{m}^{3} \mathrm{~s}^{-1}\right)\end{array}$ \\
\hline Ter & 208 & 2960 & Pyrenees. 2910 & 13.9 \\
\hline Riera de Capaspre* & $<10$ & $<100$ & Coastal Hills. 421 & -- \\
\hline Riera de Sobirans* & $<10$ & $<100$ & Coastal Hills. 552 & -- \\
\hline Riera de Cirera* & $<10$ & $<100$ & Coastal Hills. 405 & -- \\
\hline Besòs & 17 & 1023 & Pre-Coastal Hills. 1394 & 4.3 \\
\hline Rieres de Barcelona* & $<10$ & $<100$ & Coastal Hills. 550 & -- \\
\hline Llobregat & 157 & 4925 & Pre-Pyrenees. 2500 & 20.8 \\
\hline Francolí & 85 & 857 & Pre-Coastal Hills. 412 & 1.2 \\
\hline Ebro & 911 & 85001 & Cantabrian Mts. c. 1000 & 493.8 \\
\hline Segre, tributary Ebro R. & 265 & 12880 & Pyrenees. 3143 & 100.2 \\
\hline Turia & 280 & 6394 & Iberian Mts. 1830 & 10.0 \\
\hline Júcar & 498 & 21579 & Universales Mts. 1700 & 29.2 \\
\hline Segura & 325 & 19525 & Segura Mts. 2000 & 1.0 \\
\hline Argos, tributary Segura R. & 42 & 506 & Pre-Coastal Hills. 900 & 0.5 \\
\hline Guadalmedina & 25 & 180 & Camarolos Mts. 1500 & 1.0 \\
\hline
\end{tabular}

*Uadi: Non-permanent river (Improved from Barriendos and Rodrigo, 2006). 
Table 2. Classification categories of the flood cases.

\begin{tabular}{|c|l|l|}
\hline Category & Barriendos et al. (1998) & Wetter et al. (2011) \\
\hline 1 & ORD: Ordinary & Me: Minor event \\
\hline 2 & EXT: Extraordinary & Se: Severe event \\
\hline 3 & CAT: Catastrophic & Ce: Catastrophic \\
\hline
\end{tabular}


Table 3. Evolution of data availability for historical floods in Catalonia and Spanish Mediterranean Basin

\begin{tabular}{|l|l|c|c|}
\hline REFERENCE & AREA & $\begin{array}{c}\text { DATA } \\
\text { SERIES }\end{array}$ & TOTAL FLOODS \\
\hline Barriendos et al. (1998, p. 477) & Spanish Med. Basin & 9 & 207 \\
\hline Llasat et al. (2005, p. 36) & Catalonia (NE Spain) & 8 & 477 \\
\hline Barriendos et al. (2006, p. 768) & Spanish Med. Basin & 23 & 1060 \\
\hline Barrera-Escoda et al. (2015, p. 468) & Catalonia (NE Spain) & 12 & 899 \\
\hline Present w ork & Spanish Med. Basin & 27 & 2467 \\
\hline
\end{tabular}


Table 4. Data availability for historical flood chronologies. Comparison between previous work (Barriendos and Rodrigo, 2006) and present work. The location for the Mediterranean Consistent Long Series is available in Figure 1.

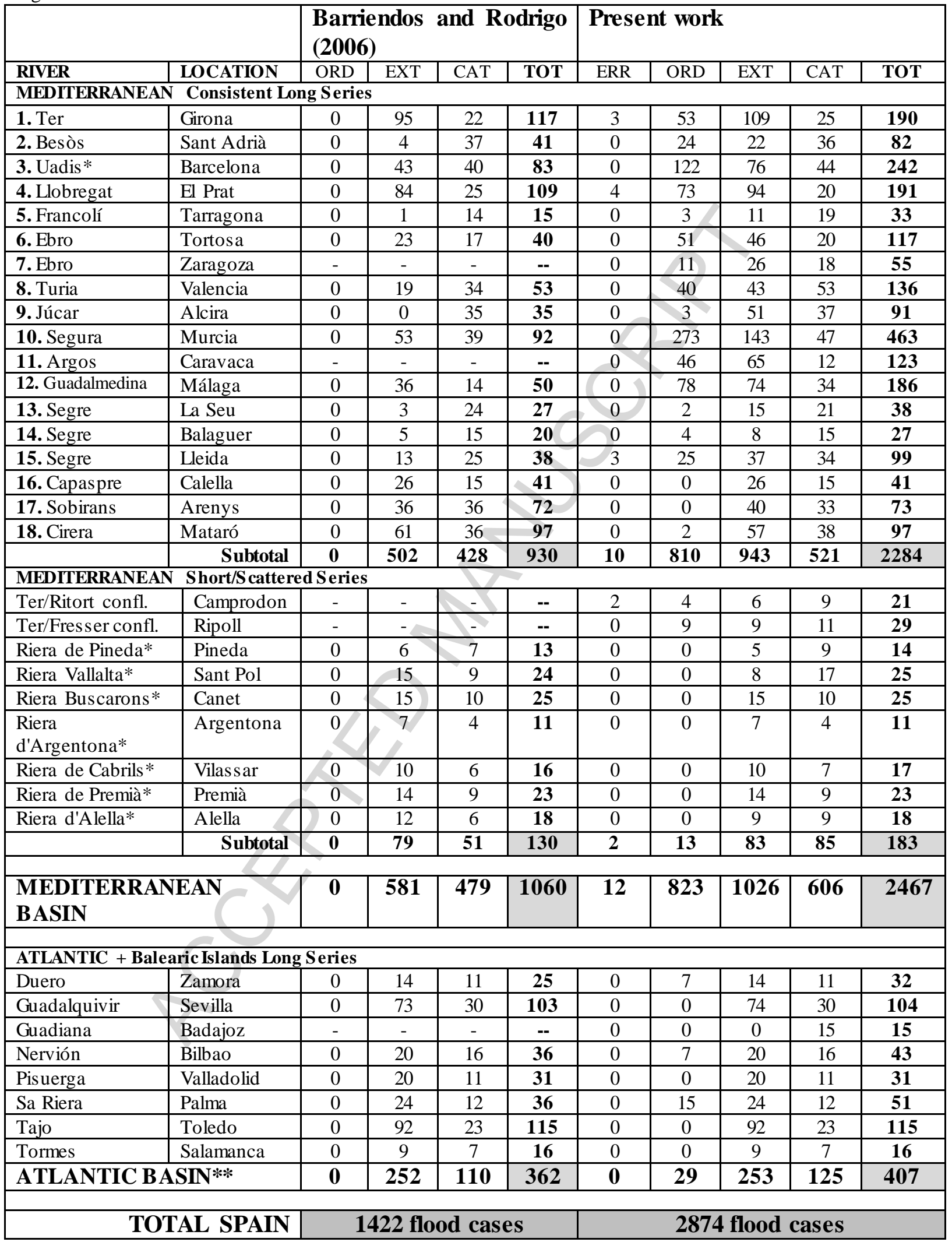

ORD refers to the number of Level 1 floods (Ordinary floods); EXT refers to the number of Level 2 floods (Extraordinary floods); CAT refers to the number of Level 3 floods (Catastrophic floods); Finally ERR refers to the number of wrongful floods detected.

(*) Coastal non-permanent rivers 
(**) Atlantic Basin + Balearic Islands Long Series

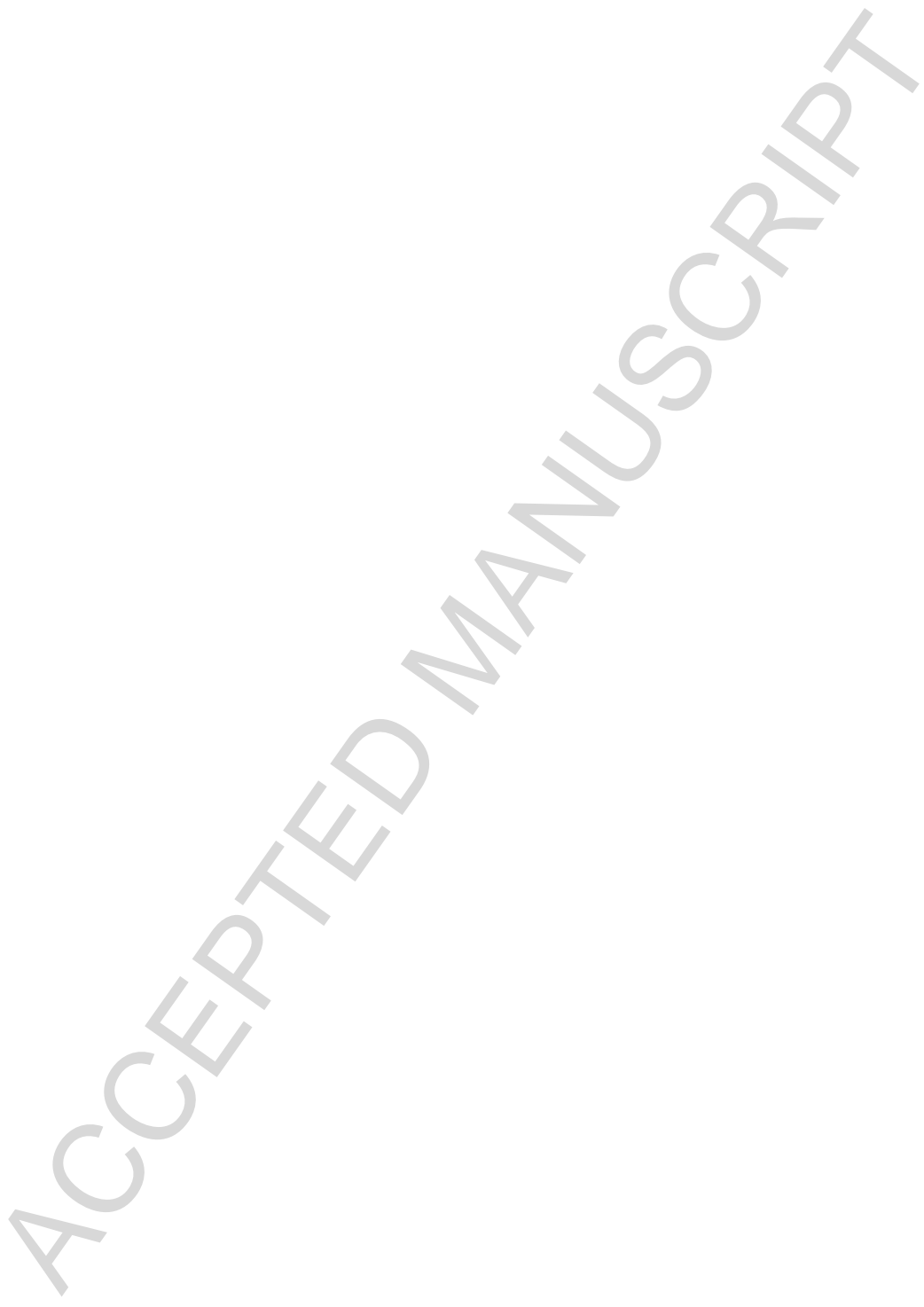


Table 5. Basic characteristics of locations of historical flood chronologies.

\begin{tabular}{|c|c|c|c|c|c|c|c|c|}
\hline Nr. & RIVER & TOWN & LOCATION & $\begin{array}{c}\text { ALT. } \\
(\text { m.a.s.l. })\end{array}$ & $\begin{array}{l}\text { First } \\
\text { Year } \\
\text { (CE) }\end{array}$ & $\begin{array}{l}\text { Last } \\
\text { Year } \\
\text { (CE) }\end{array}$ & $\begin{array}{c}\text { Duration } \\
\text { (Years) }\end{array}$ & Status \\
\hline 1 & Ter & Girona & $41^{\circ} 59 \mathrm{~N}-02^{\circ} 49 \mathrm{E}$ & $68 \mathrm{~m}$ & 1322 & 1996 & 675 & Improved \\
\hline 2 & Besòs & $\begin{array}{l}\text { Sant } \\
\text { Adrià }\end{array}$ & $41^{\circ} 25 \mathrm{~N}-02^{\circ} 13 \mathrm{E}$ & $4 \mathrm{~m}$ & 1402 & 2014 & 613 & Improved \\
\hline 3 & Uadis & Barcelona & $41^{\circ} 23 \mathrm{~N}-02^{\circ} 10 \mathrm{E}$ & $15 \mathrm{~m}$ & 1389 & 2002 & 614 & Improved \\
\hline 4 & Llobregat & El Prat & $41^{\circ} 19 \mathrm{~N}-02^{\circ} 05 \mathrm{E}$ & $4 \mathrm{~m}$ & 1369 & 1996 & 628 & Improved \\
\hline 5 & Francolí & Tarragona & $41^{\circ} 06 \mathrm{~N}-01^{\circ} 14 \mathrm{E}$ & $2 \mathrm{~m}$ & 1597 & 1994 & 398 & Improved \\
\hline 6 & Ebro & Tortosa & $40^{\circ} 48 \mathrm{~N}-00^{\circ} 31 \mathrm{E}$ & $8 \mathrm{~m}$ & 1301 & 2015 & 715 & Improved \\
\hline 7 & Ebro & Zaragoza & $\begin{array}{llll}41^{\circ} & 39 & \mathrm{~N}-00^{\circ} & 52 \\
\mathrm{~W} & & & \end{array}$ & $203 \mathrm{~m}$ & 1301 & 2003 & 703 & New \\
\hline 8 & Turia & Valencia & $\begin{array}{llll}39^{\circ} & 28 & \mathrm{~N}-00^{\circ} & 22 \\
\mathrm{~W} & & & \end{array}$ & $12 \mathrm{~m}$ & 1321 & 2010 & 690 & Improved \\
\hline 9 & Júcar & Alcira & $\begin{array}{llll}39^{\circ} & 09 & \mathrm{~N}-00^{\circ} & 26 \\
\mathrm{~W} & & & \\
\end{array}$ & $20 \mathrm{~m}$ & 1320 & 2010 & 691 & Improved \\
\hline 10 & Segura & Murcia & $\begin{array}{llll}37^{\circ} & 58 & \mathrm{~N}-01^{\circ} & 07 \\
\mathrm{~W} & & & \\
\end{array}$ & $42 \mathrm{~m}$ & 1301 & 2016 & 716 & Improved \\
\hline 11 & Argos & Caravaca & $\begin{array}{llll}38^{\circ} & 06 & \mathrm{~N}-01^{\circ} & 51 \\
\mathrm{~W} & & & \end{array}$ & $625 \mathrm{~m}$ & 1591 & 2016 & 426 & New \\
\hline 12 & Guadalmedina & Málaga & $\begin{array}{llll}36^{\circ} & 42 & \mathrm{~N}-04^{\circ} & 25 \\
\mathrm{~W} & & & \end{array}$ & $5 \mathrm{~m}$ & 1544 & 2016 & 473 & Improved \\
\hline 13 & Segre & La Seu & $42^{\circ} 21 \mathrm{~N}-01^{\circ} 27 \mathrm{E}$ & $673 \mathrm{~m}$ & 1453 & 1997 & 545 & Improved \\
\hline 14 & Segre & Balaguer & $41^{\circ} 47 \mathrm{~N}-00^{\circ} 48 \mathrm{E}$ & $215 \mathrm{~m}$ & 1617 & 2016 & 400 & Improved \\
\hline 15 & Segre & Lleida & $41^{\circ} 36 \mathrm{~N}-00^{\circ} 37 \mathrm{E}$ & $148 \mathrm{~m}$ & 1306 & 1993 & 688 & Improved \\
\hline 16 & Capaspre & Calella & $41^{\circ} 36 \mathrm{~N}-02^{\circ} 39 \mathrm{E}$ & $4 \mathrm{~m}$ & 1755 & 1999 & 245 & $\begin{array}{c}\text { No } \\
\text { change }\end{array}$ \\
\hline 17 & Sobirans & Arenys & $41^{\circ} 34 \mathrm{~N}-02^{\circ} 33 \mathrm{E}$ & $5 \mathrm{~m}$ & 1687 & 2002 & 316 & Improved \\
\hline 18 & Cirera & Mataró & $41^{\circ} 32 \mathrm{~N}-02^{\circ} 26 \mathrm{E}$ & $22 \mathrm{~m}$ & 1737 & 1999 & 263 & $\begin{array}{c}\text { No } \\
\text { change }\end{array}$ \\
\hline
\end{tabular}

*Location of the flood series is available in Figure 1. 
Table 6. Trends in floods and population affected by floods since 1857. To calculate trends, we have used Hirsch and Slack (1984) nonparametric test, which is based on Mann-Kendall range. The trial version of XLSTAT software (Addinsoft, 2018) was used to calculate it. The Mann-Kendall test provides a level of statistical significance ( $\mathrm{p}$-value). The threshold of significance chosen was $95 \%$, which indicates that $\mathrm{p}$-values above 0.05 should lead to rejecting the hypothesis of a trend in the series (symbol $=$ and yellow cell). When the p-value is less than 0.05 , the trend can be positive (symbol + and red cell) or negative (symbol - and green cell).

\begin{tabular}{|c|c|c|c|c|c|c|c|c|c|c|c|c|c|c|c|c|c|c|c|}
\hline & 颉 & 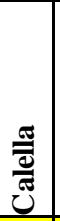 & 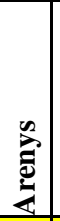 & 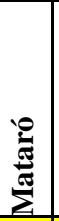 & 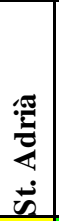 & 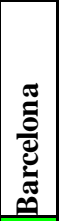 & 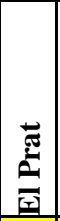 & 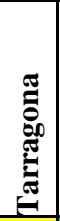 & $\frac{\pi}{4}$ & 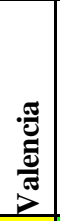 & 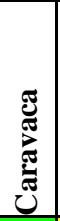 & 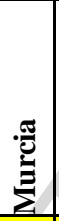 & 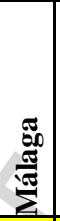 & 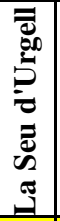 & 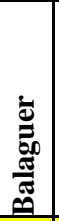 & $\frac{\pi}{\frac{\pi}{2}}$ & 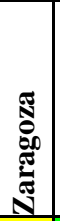 & 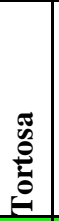 & 这 \\
\hline CAT Floods & $=$ & $=$ & $=$ & $=$ & $=$ & - & $=$ & $=$ & - & $=$ & - & $=$ & $=$ & $=$ & $=$ & $=$ & $=$ & - & - \\
\hline EXT Floods & + & + & + & + & $=$ & + & $=$ & + & $=$ & - & $=$ & $=$ & + & $=$ & $=$ & $=$ & $=$ & $=$ & $=$ \\
\hline Total floods & + & + & + & + & $=$ & $=$ & $=$ & $=$ & $=$ & - & $=$ & $=$ & + & $=$ & $=$ & $=$ & $=$ & - & $=$ \\
\hline $\begin{array}{l}\text { Affected Population by CAT } \\
\text { Floods }\end{array}$ & $=$ & $=$ & $=$ & $=$ & $=$ & $=$ & $=$ & $=$ & - & $=$ & - & $=$ & $=$ & $=$ & $=$ & $=$ & $=$ & - & $=$ \\
\hline $\begin{array}{l}\text { Affected population by EXT } \\
\text { Floods }\end{array}$ & + & + & + & + & $=$ & + & $=$ & + & $=$ & - & $=$ & $=$ & + & + & $=$ & $=$ & $=$ & $=$ & + \\
\hline $\begin{array}{l}\text { Total affected population by } \\
\text { floods }\end{array}$ & + & + & + & + & $=$ & + & $=$ & $=$ & $=$ & - & $=$ & $=$ & + & $=$ & $=$ & $=$ & $=$ & - & + \\
\hline
\end{tabular}




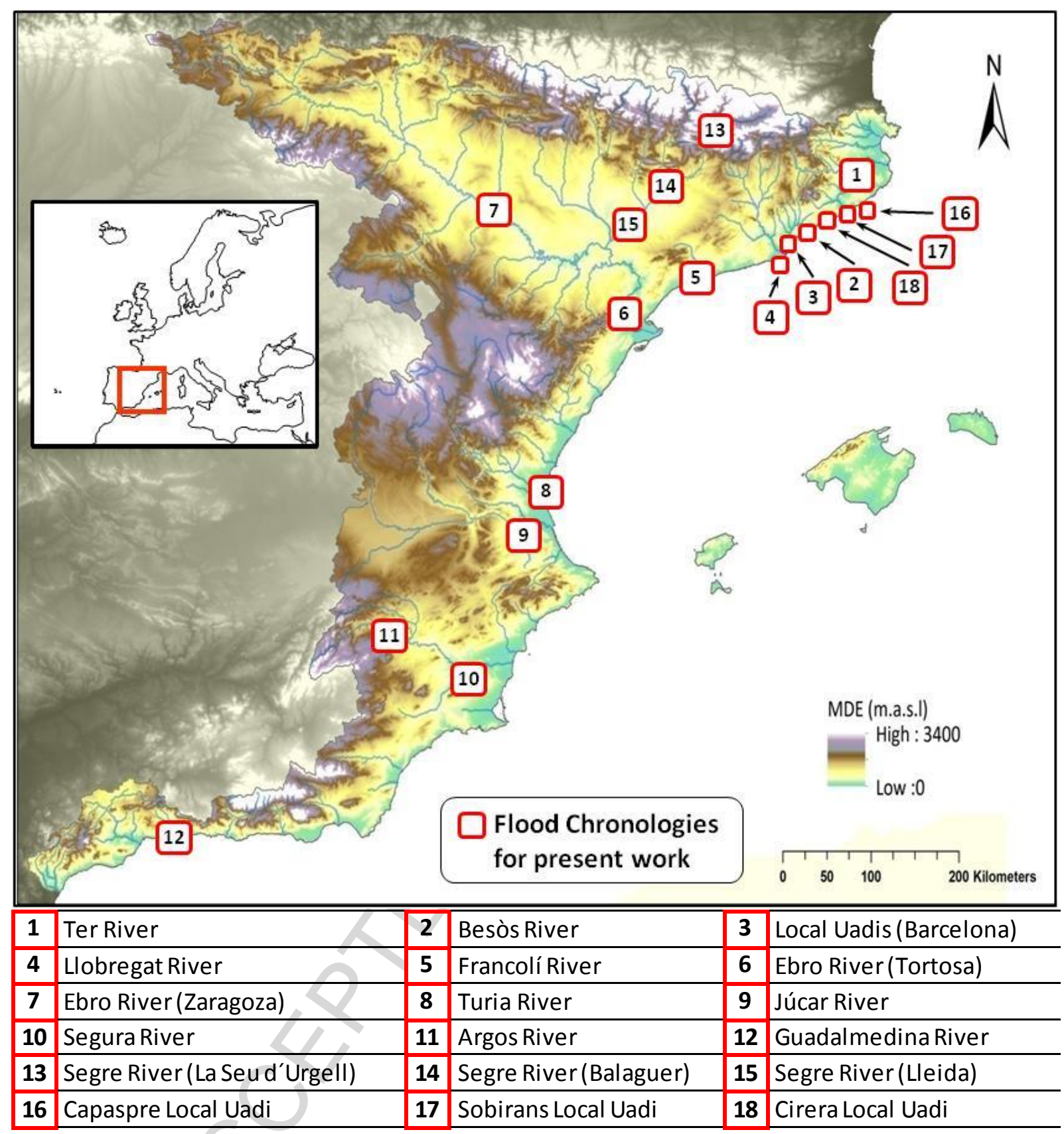

Figure 1. Location of historical flood chronologies. Additional information about basins and flood chronologies in Tables 2, 4 and 5. 
Girona. Ter/Onyar Rivers
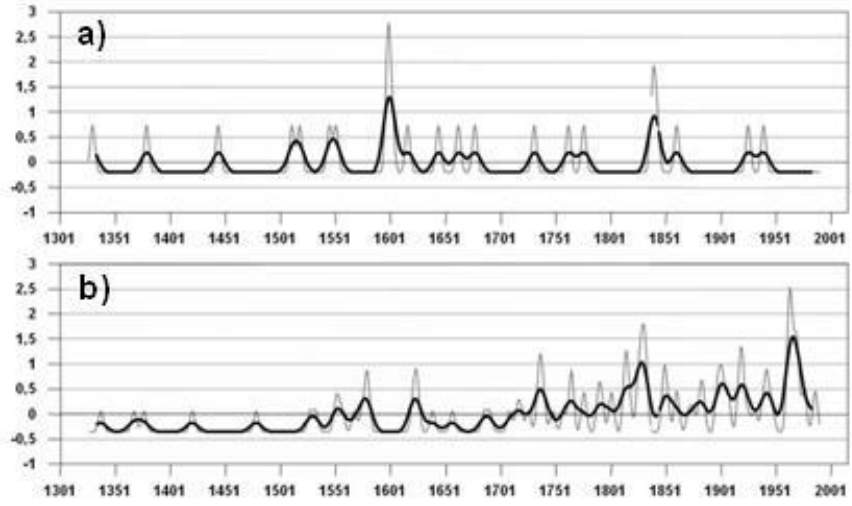

Mouth. Llobregat River
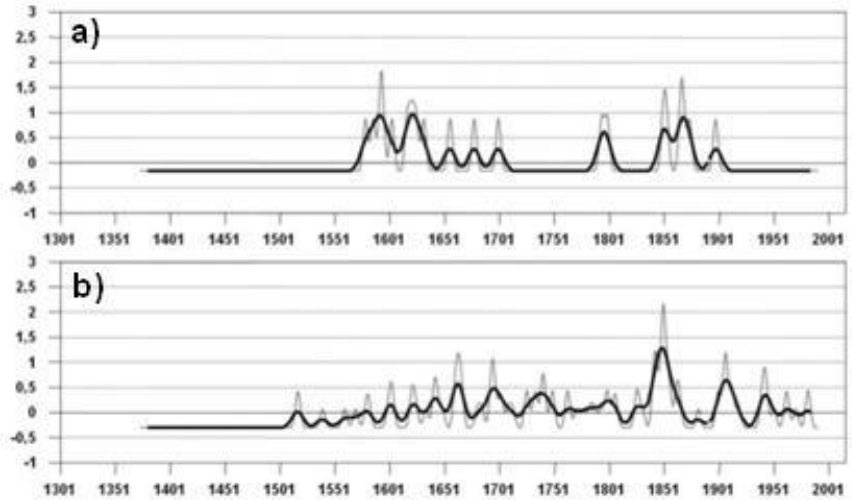

St. Adrià. Besòs River

a)

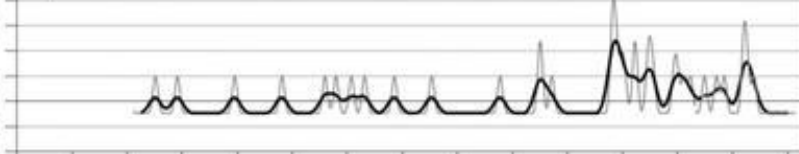

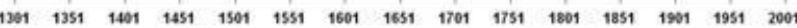
b)

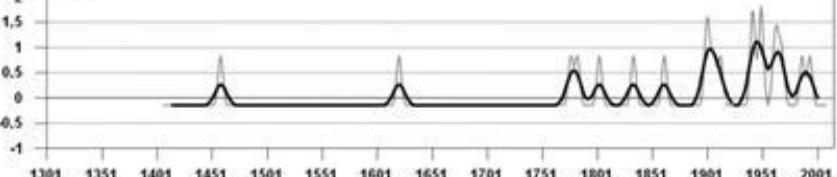

Tarragona. Francolí River

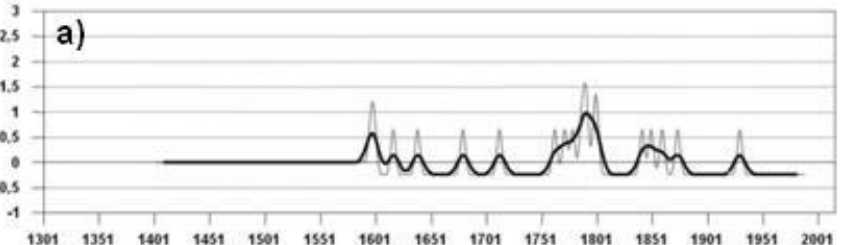

b)

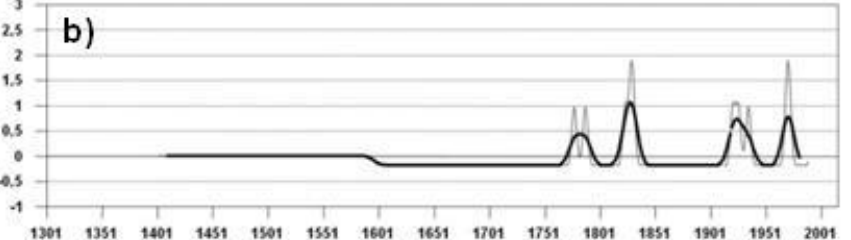

Figure 2.

Historical Flood Chronology. Northern Rivers.
a) Catastrophic Floods
b) Extraordinary Floods

Thin line: 13 y. Filter Thick line: 31 y. Filter 
Calella de Mar. Capaspre River

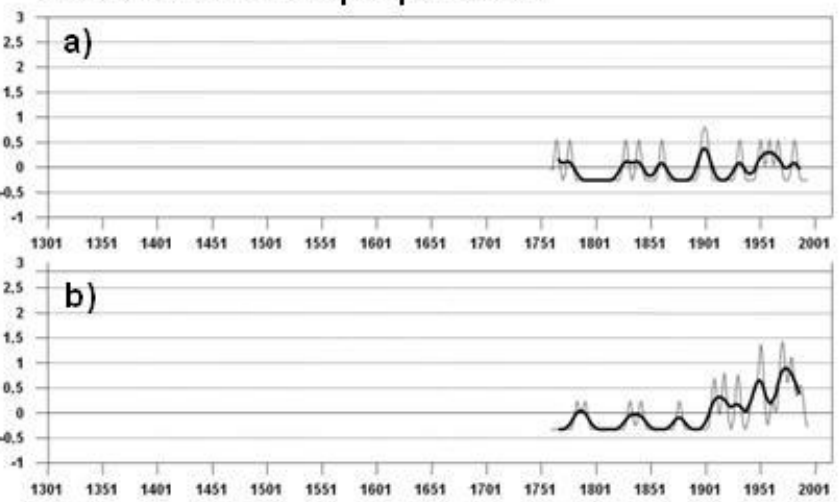

Mataró. Cirera River
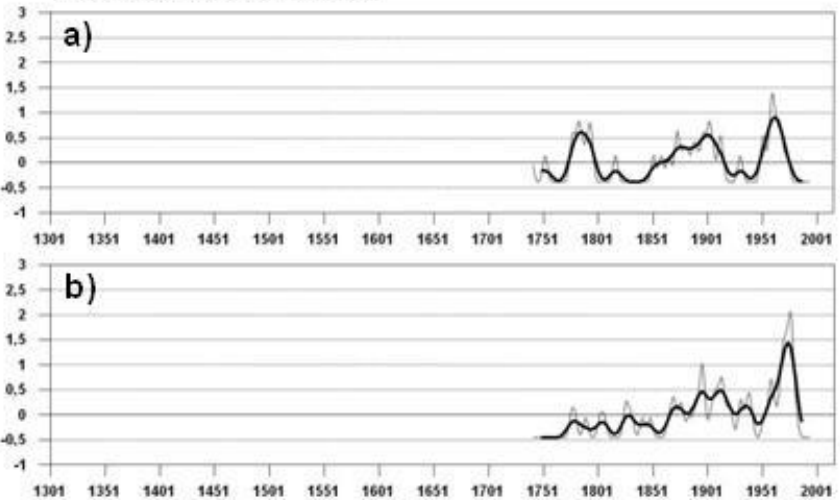

Arenys de Mar. Sobirans River

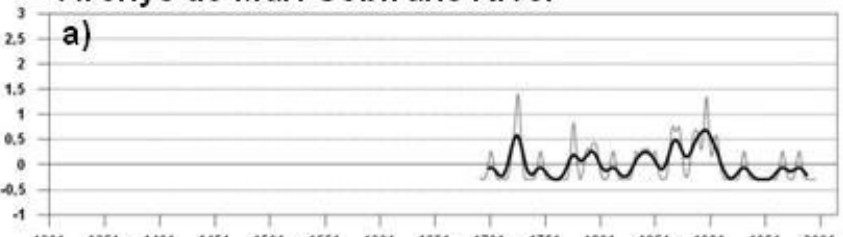

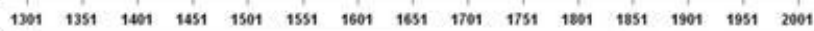

b)

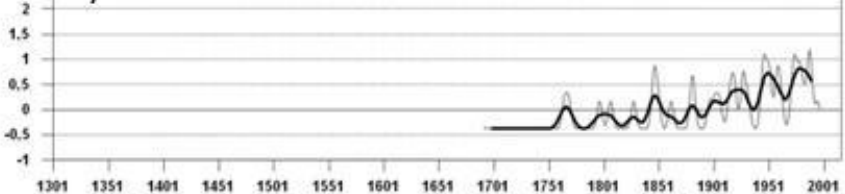

Barcelona. Coastal Rivers

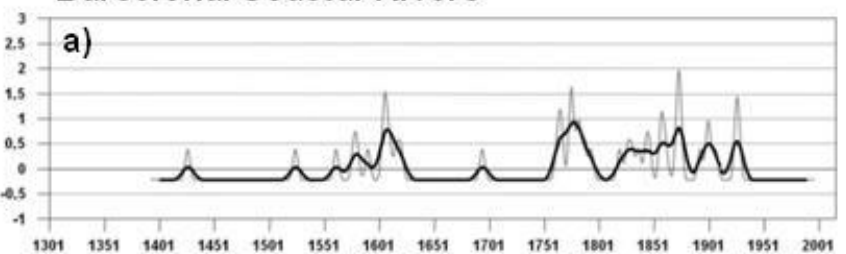

b)

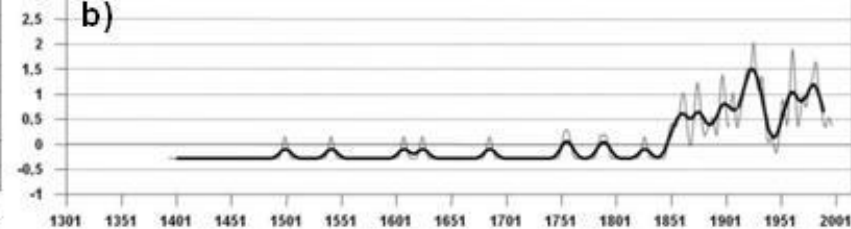

Figure 3.

Historical Flood Chronology. Ephemeral Coastal Rivers
a) Catastrophic Floods
b) Extraordinary Floods

Thin line: $13 \mathrm{y}$. Filter Thick line: $31 \mathrm{y}$. Filter 
La Seu d'Urgell. Segre River

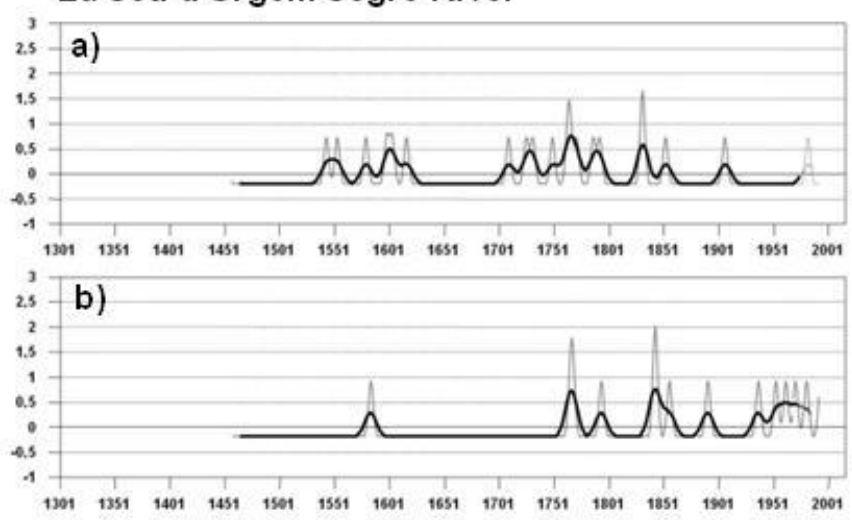

Balaguer. Segre River

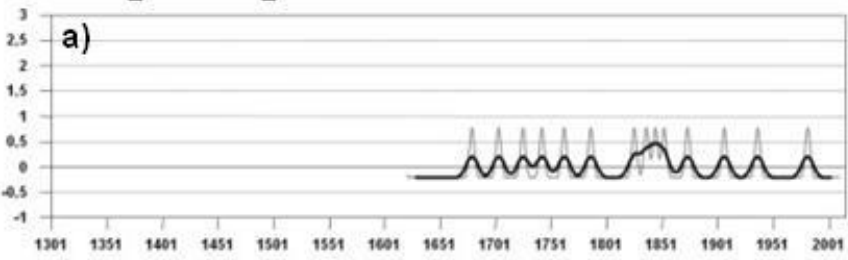

b)

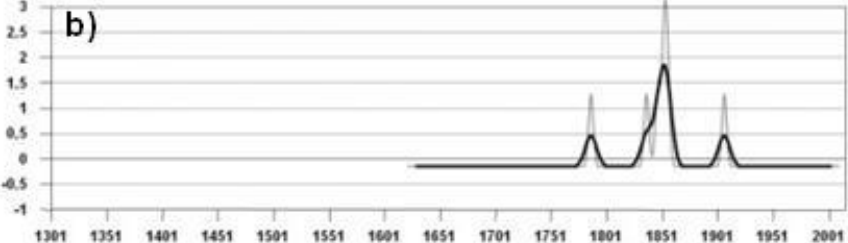

Lleida. Segre River
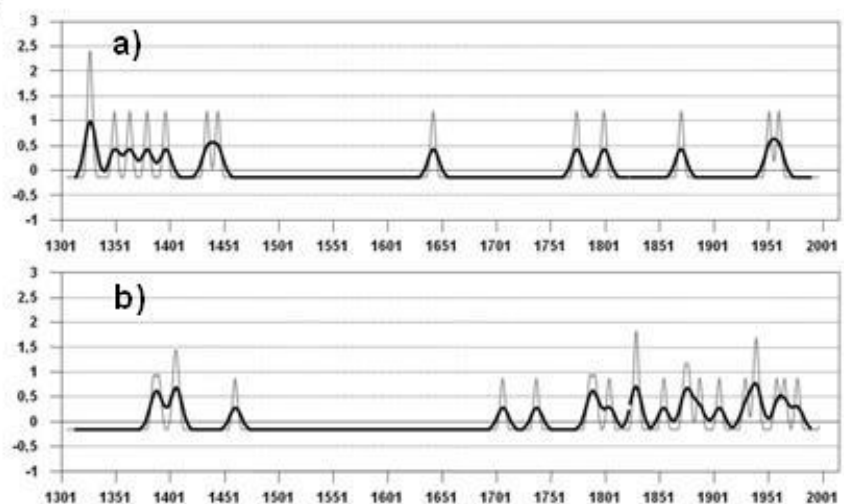

Zaragoza. Ebro River

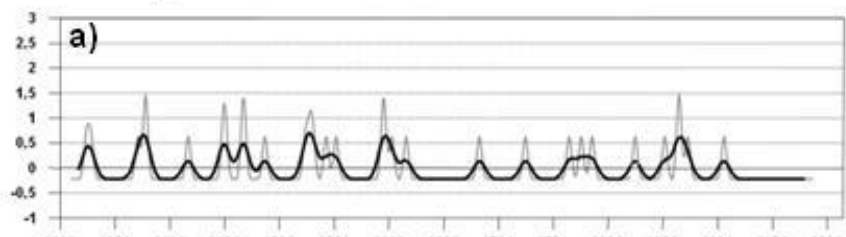

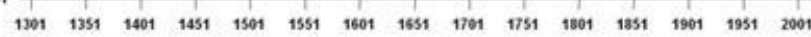
b)

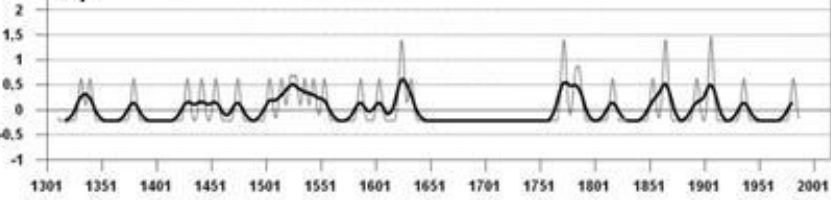

Tortosa. Ebro River

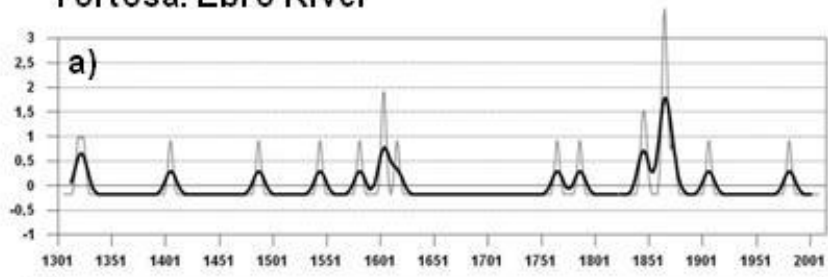

b)

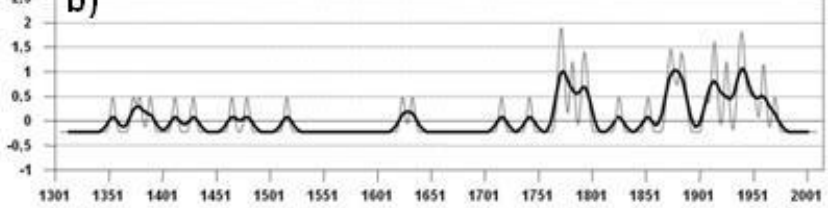

Figure 4.

Historical Flood Chronology. Segre/Ebro Rivers
a) Catastrophic Floods
b) Extraordinary Floods

Thin line: 13 y. Filter Thick line: 31 y. Filter 

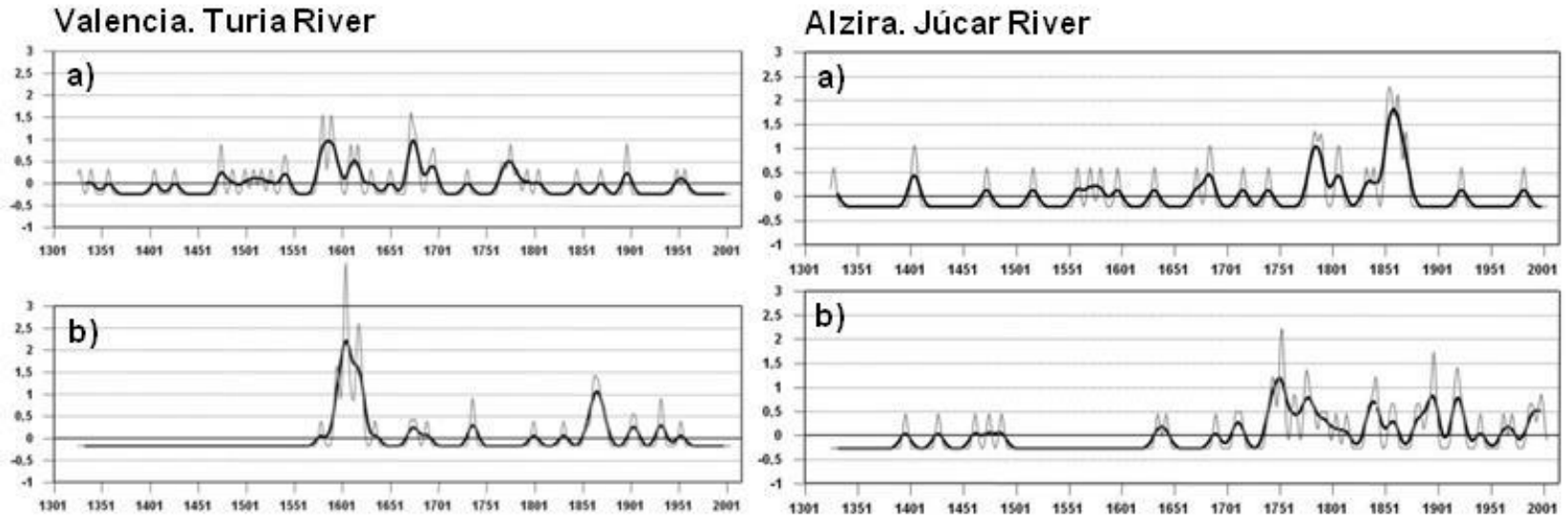

Figure 5.

Historical Flood Chronology. Central Rivers
a) Catastrophic Floods
b) Extraordinary Floods

Thin line: 13 y. Filter Thick line: 31 y. Filter 
Murcia. Segura River

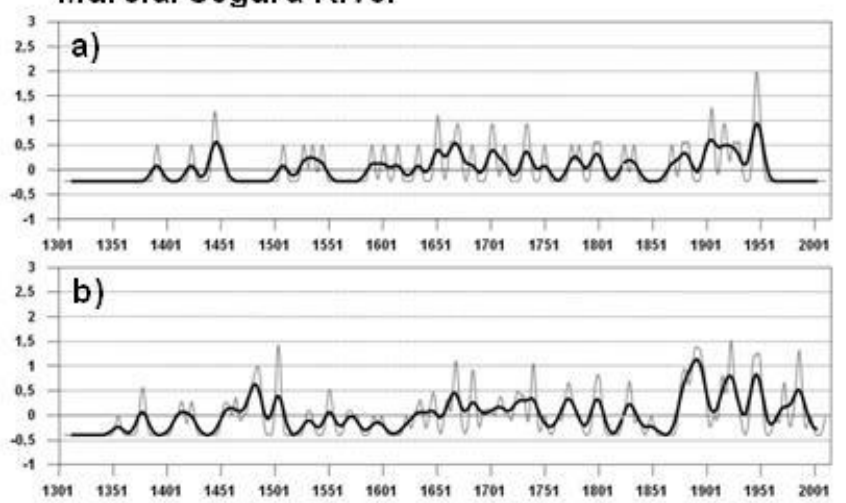

\section{Caravaca. Argos River}

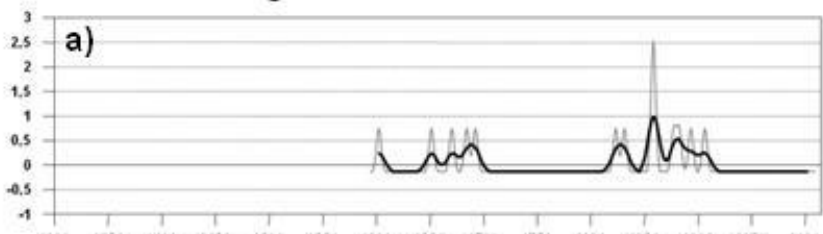

$\begin{array}{lllllllllllllll}1351 & 1401 & 1451 & 1501 & 1551 & 1601 & 1651 & 1704 & 1751 & 1809 & 1951 & 1909 & 1951 & 2004\end{array}$

b)

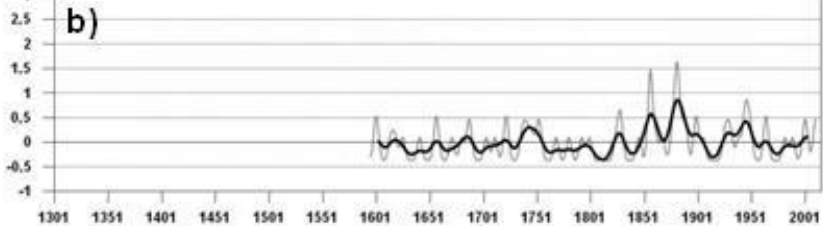

Málaga. Guadalmedina River

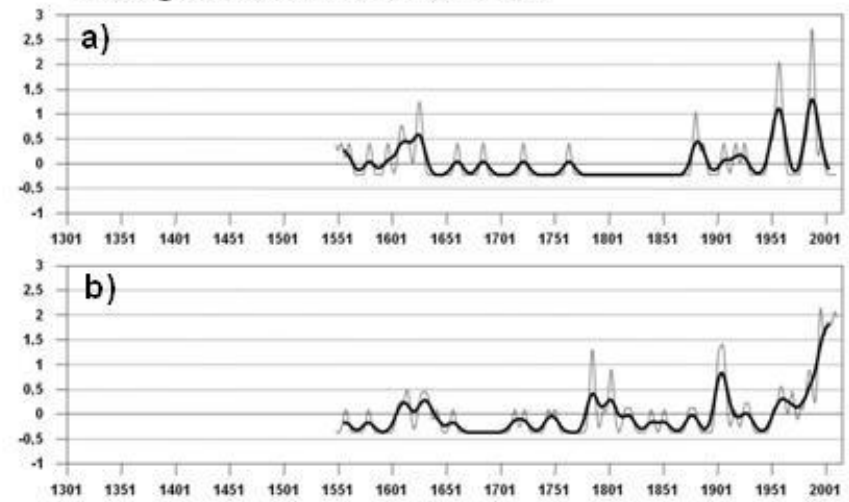

Figure 6.

Historical Flood Chronology. Southern Rivers
a) Catastrophic Floods
b) Extraordinary Floods

Thin line: 13 y. Filter Thick line: 31 y. Filter 

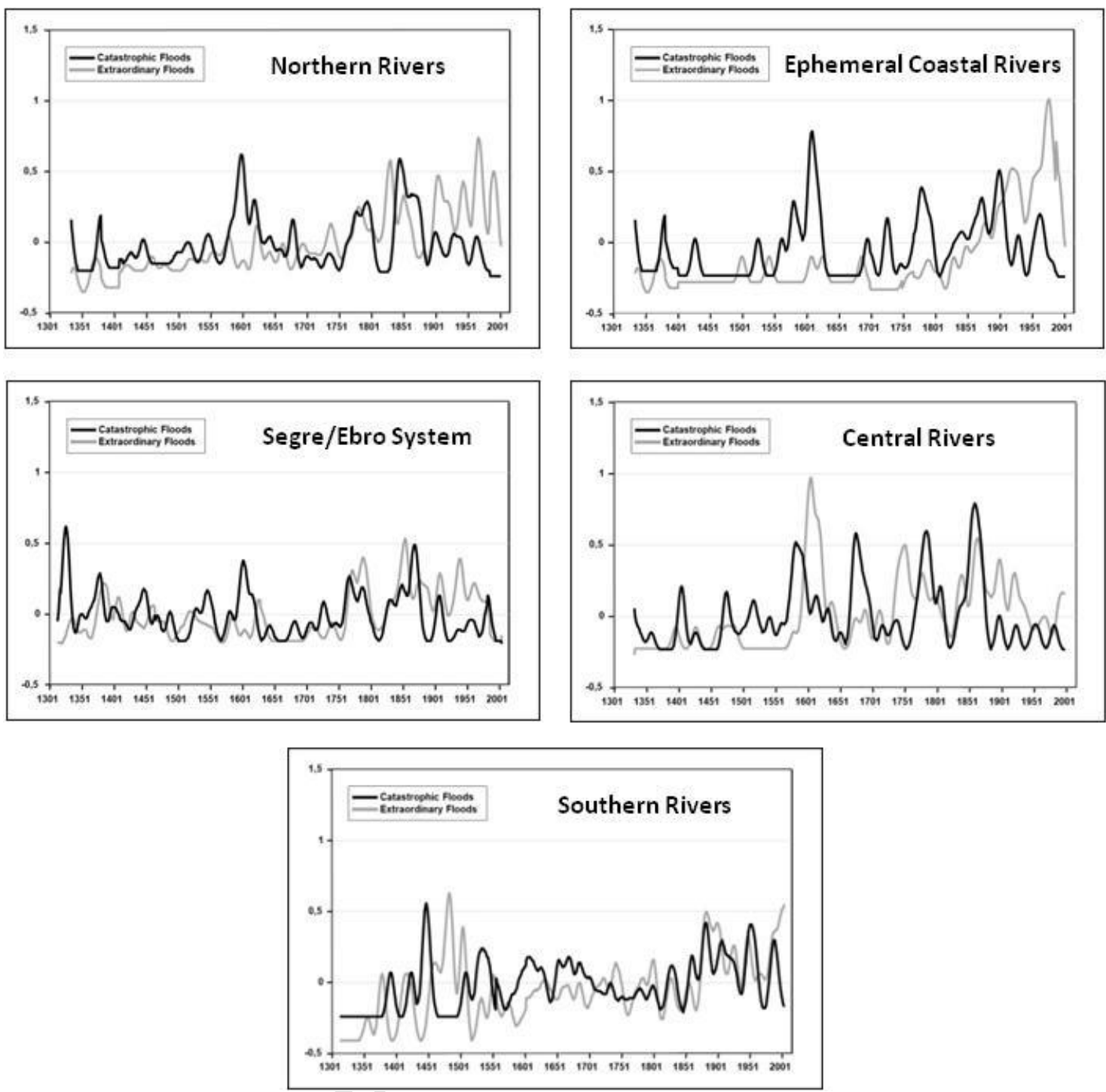

Figure 7. Flood Chronology Synthesis (31y. Gaussian filter). 


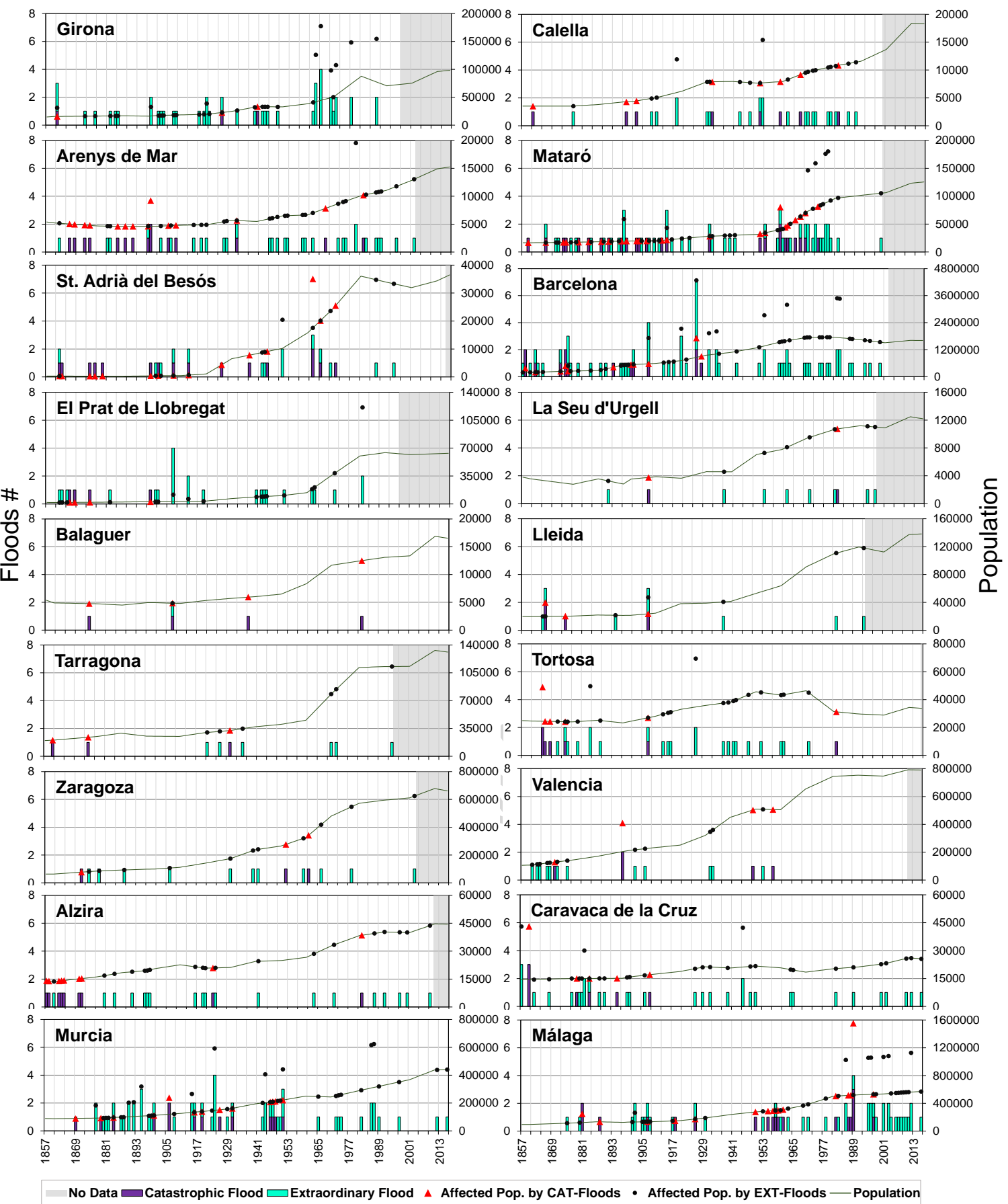

Figure 8. Spatiotemporal variability of floods and population affected by the floods since 1857. The blue bars show the annual frequency of extraordinary floods, the violet bars show the annual frequency of catastrophic floods. The solid line represents the evolution of the annual population. Black dots and red triangles report the population affected by, respectively, extraordinary and catastrophic floods. Finally, gray areas report periods with flood data gaps. 


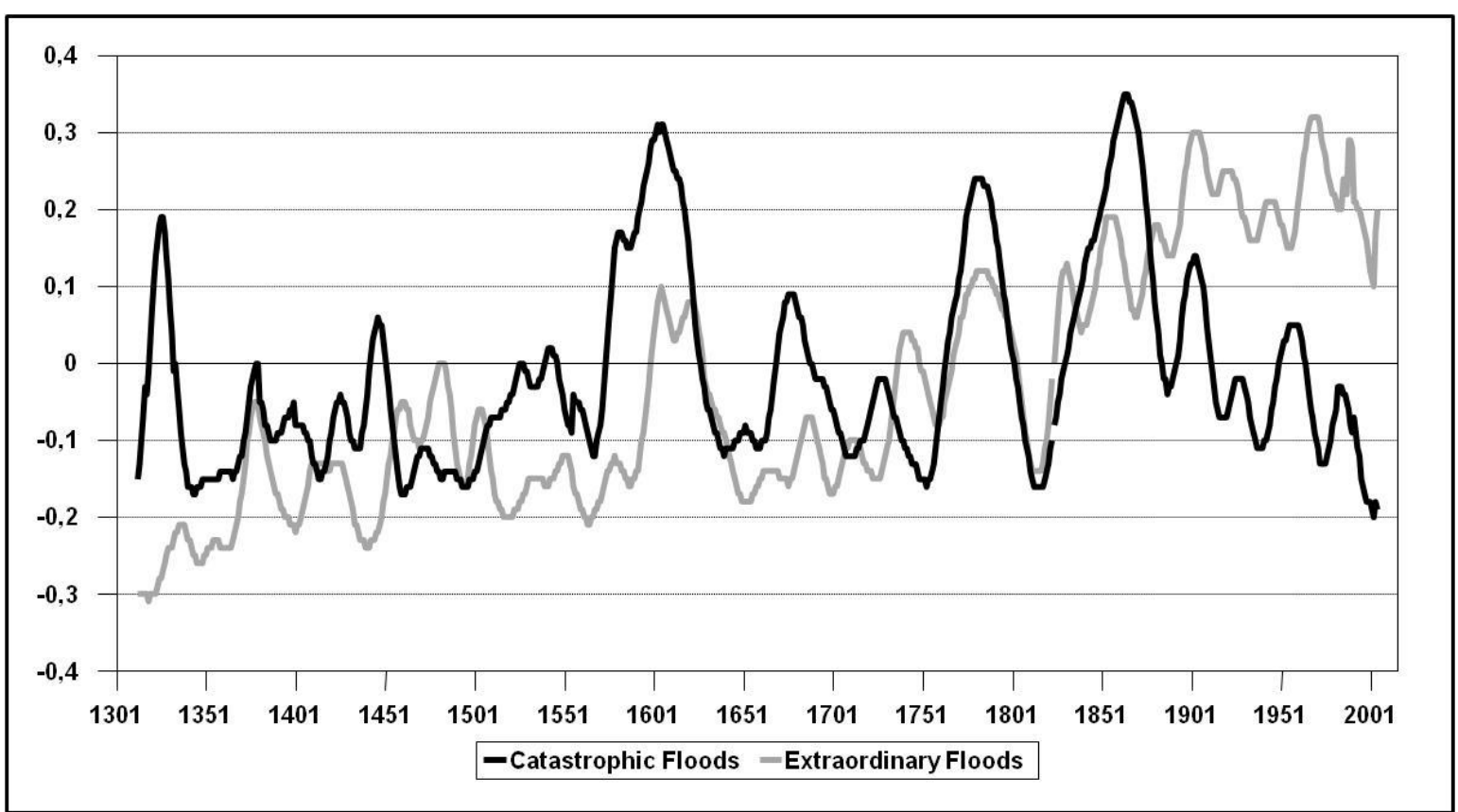

Figure 9. Summary of all flood chronologies. 31y. Gaussian filter. 
Highlights

- The study of floods from documentary and bibliographical sources within the specialty of historical climatology has a good background in Spanish rivers of Western Mediterranean Basin.

- Geographical and climatic context of Western Mediterranean Basin is complex and diverse, making difficult the research and analysis of natural hazards. In contrast, historical documentary sources provide relatively homogeneous, continuous, consistent and reliable information to establish chronologies of events that easily exceed 500 years.

- Since 2013, PREDIFLOOD Spanish project, continued after 2016 by MEDIFLOOD Spanish project, have improved and updated the available information using new cataloging and classifying methodologies. All types of events and locations can be analyzed, from small basins with nonpermanent flows to large river systems.

- Results of this new methodological approach offer important improvement of data availability, arriving to $27 \mathrm{flood}$ series and 2647 flood cases for Spanish Mediterranean Basin.

- First approach to this general information has two basic objectives. First, the characterization of climatic variability in the Western Mediterranean Basin focused on extreme hydrometeorological events. Different climatic oscillations are detected between 14th and 19th centuries, related to Little Ice Age. Second, the perception of incidence of social factors in flood frequency and severity, defining impact of large hydraulic infrastructures, demographical and urbanistic growing. 